\title{
Fairy Tale Femininities: A Discourse Analysis of Snow White Films 1916-2012
}

\author{
Lisbet Rosa Dam
}

A thesis submitted in partial fulfillment of the requirements for the degree of Master of Science at the Victoria University of Wellington

Victoria University of Wellington

2014 


\section{ACKNOWLEDGEMENTS}

Many thanks to my supervisor Dr Sue Jackson, her help and expertise are deeply appreciated. I am grateful for the continuous support she has given me, her feedback, and her belief in my abilities. Her passion and enthusiasm for qualitative research has inspired me immensely. Thank you Sue for investing your time in me, your assistance has been invaluable.

Thank you Sophie for being such an amazing 'office buddy,' sharing an office with you has helped transform a stressful year into an enjoyable one. Our discussions of research, concepts, and our theses (and dresses) has been incredibly helpful.

Finally, a big thanks to my flatmates, friends and family. Your ideas and support are hugely appreciated. 


\begin{abstract}
Fairy tales are enduring cultural texts that have enjoyed wide appeal and the continuing popularity of the fairy tale can be seen in the recent proliferation of media employing fairy tale narratives. Fairy tales provide a site of meaning about femininity and masculinity and examining them over time identifies versions of gender that are prized or denigrated within specific social, historical moments. This project was interested in the continuities and divergences in these gendered discourses across time. Although there has been considerable academic interest in fairy tales and gender, few studies have approached the topic from a genealogical perspective. This research extends the current literature through a genealogical analysis of five Snow White films from 1916 to 2012 in addition to incorporating an analysis in relation to a contemporary postfeminist, neoliberal social climate. The research employed a feminist poststructuralist framework and utilised thematic and genealogical Foucauldian discourse analysis to analyse the data. Discursive analyses found enduring discourses of traditional femininity across the films which centrally organised around a binary construction of femininity as 'good' or 'bad.' A moral discourse worked to construct 'good' femininity as prized and bad femininity as punished. Alongside persistent discourses of femininity, however, a newer postfeminist femininity was evident in recent versions of the fairy tale. Consistent with a postfeminist, neoliberal discourse that highlights the importance of the body, analyses found an increased emphasis on beauty and the vast effort required to maintain it. Another postfeminist shift in the tale was the invoking of a girl power discourse to construct Snow as a competent fighter and leader. However, the complex entanglement of discourses of femininity in contemporary society is highlighted by the co-existence of these newer versions of femininity with traditional goals such as achieving a 'happily ever after.' From the perspective of possibilities for subjectivity, these shifts in representation appear to offer a young female audience more empowered possibilities of femininity but such power is simultaneously constrained by a complex amalgamation with traditional 'niceness' and beauty.
\end{abstract}




\section{TABLE OF CONTENTS}

ACKNOWLEDGEMENTS ..................................................................................................II

ABSTRACT ....................................................................................................................

TABLE OF CONTENTS .................................................................................................IIV

CHAPTER ONE: INTRODUCTION...............................................................................6

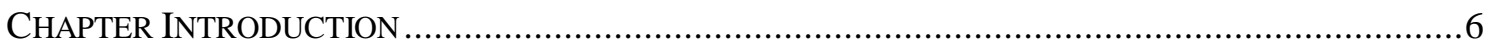

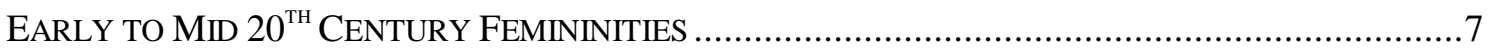

1960S TO 1980S - FEMINISM AND MEDIA FEMININITIES............................................... 9

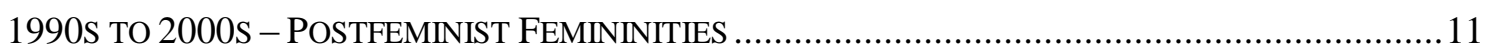

POLARITIES: GOOD VS BAD VERSIONS OF FEMININITY IN MEDIA ........................................... 16

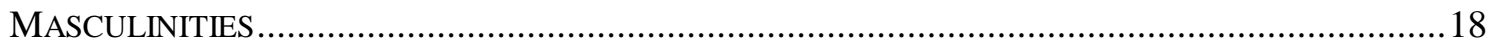

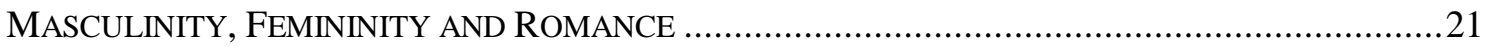

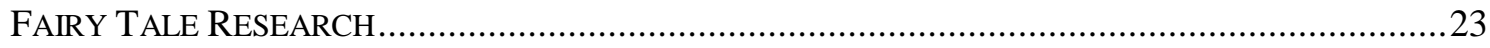

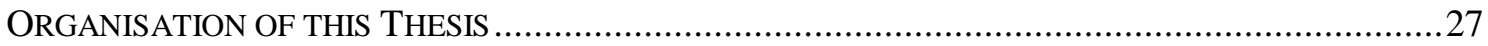

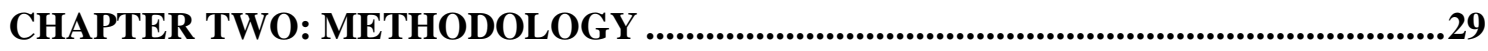

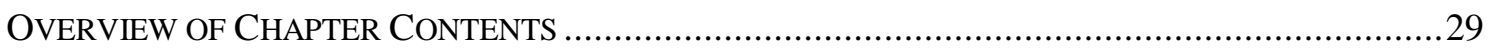

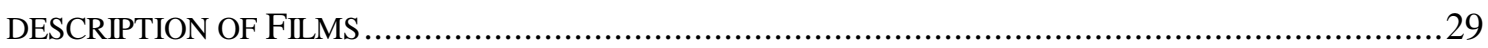

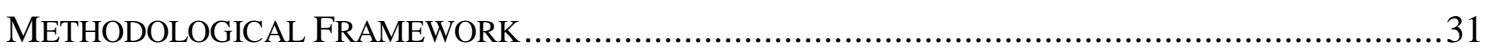

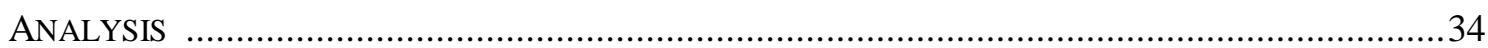

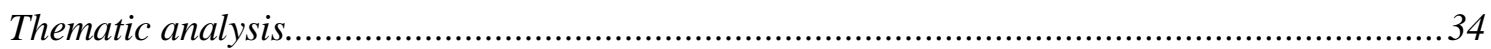

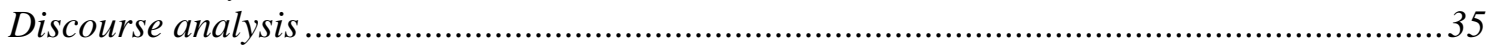

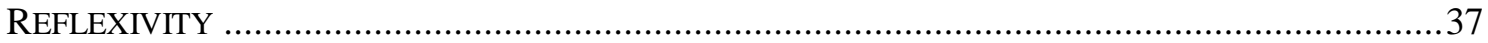

CHAPTER THREE: DISCOURSES OF FEMINININTY IN THE EARLY FILMS ........40

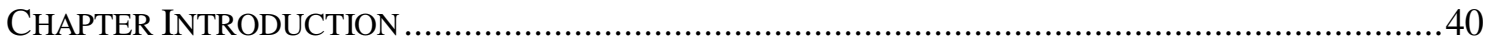

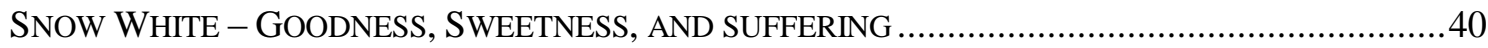

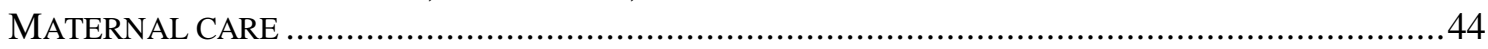

SNOW AS THE CHEERFUL HOUSEKEEPER - DOMESTICITY AND SERVITUDE ............................46

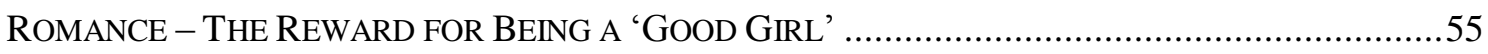

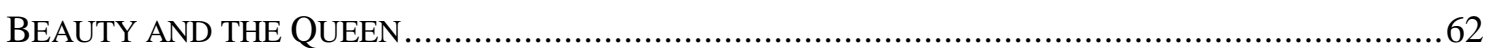

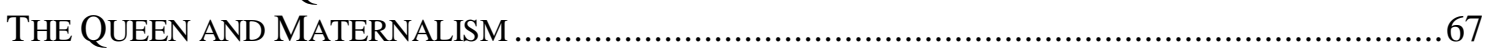

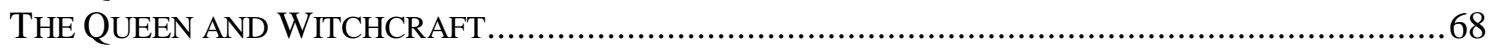

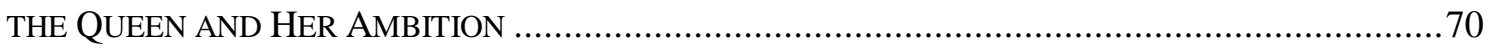

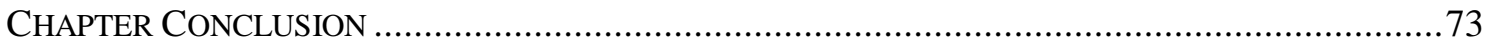

CHAPTER FOUR: DISCOURSES OF FEMININTY AND MASCULINTY IN THE

CONTEMPORARY FILMS .................................................................................................75

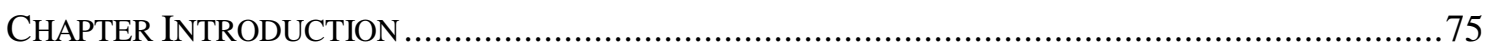

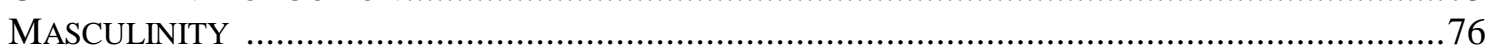

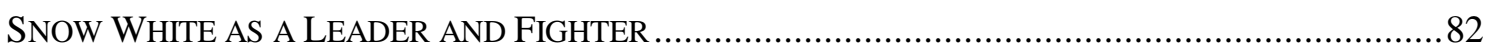

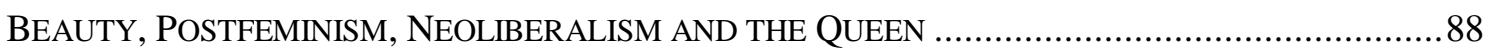

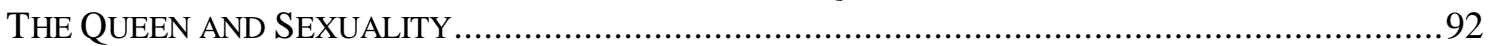

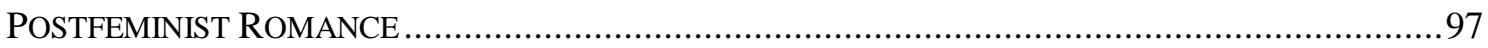

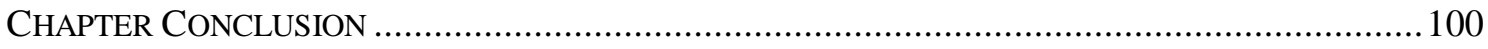




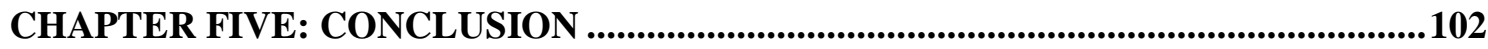

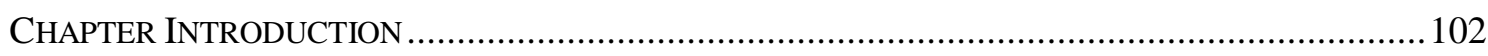

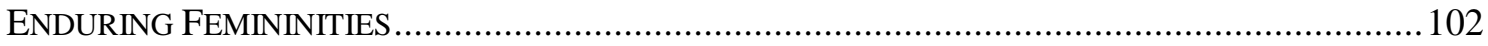

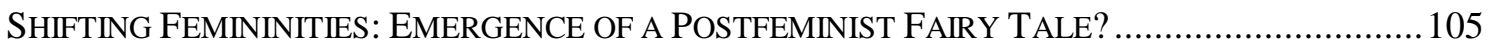

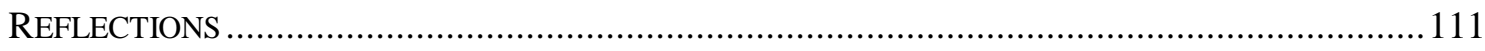

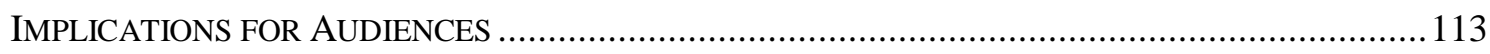

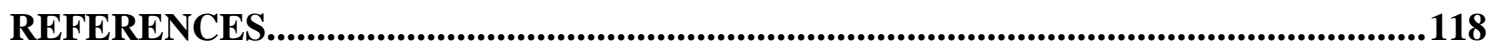




\section{CHAPTER ONE}

\section{INTRODUCTION}

\section{Chapter Introduction}

For most people in Western society, the classic fairy tales are a familiar part of their childhood. Whether these tales were presented as a film, illustrated book, or the original Grimm's tales were read to them by their parents, fairy tales are not easily forgotten. As enduring popular culture texts, fairy tales provide audiences with a readily available cultural resource for constructing gender identity (Parsons, 2004). Feminist analysis of fairy tales has been particularly interested in the feminine subjectivities made available within these tales (Rowe, 1979; Ussher, 1997). As fairy tales are heavily gendered, they have been under scrutiny for the traditional romantic narratives they espouse, particularly the fantasy of the 'happily ever after' and the hope that 'some day my Prince will come' (Ussher, 1997; Walkerdine, 1990). Although elements of these traditional narratives have enduring appeal, they have recently been reappropriated across various media platforms to include more feminist components.

While popular throughout history, fairy tales have recently experienced a resurgence in popularity, most notably with the release of a range of recent cinematic reproductions of fairy tales (eg., Hansel and Gretel: Witch Hunters (2013), Jack the Giant Slayer (2013) and Red Riding Hood (2011)) and TV shows focused on fairy tale narratives (eg. Once Upon a Time (2011) and Grimm (2011)). This current intensification of interest in fairy tales raises questions about whether and how gender conditions in these fairy tales have been transformed for a social context where gender relations have undergone significant changes from when these tales were originally written. These questions underpin the current research which undertakes an analysis of gender constructions in Snow White films from 1916 to 2012. 
This historical focus accords with the social constructionist understandings of gender that underline the research. A social constructionist perspective holds that the dominant constructions of gender prevalent in society are specific to the social and historical locations within which they are produced (Atkins, 2005; Willis, 2009). Analysis of texts in relation to historical and social contexts is valuable as it enables observation of the ways in which constructions of gender develop over time (Rothschild, 2010).

This chapter will examine the prevailing gendered discourses of femininity circulated in media from the beginning of the $20^{\text {th }}$ century through to the current late capitalist social climate. The polarity of 'good' and 'bad' femininity in media representations will also be examined. Masculinity also often centres on competing versions of masculinity, such as heroic and anti-heroic. In this chapter, the discussion of media representations of masculinity will centre on heroic masculinity, but will also examine how heroic masculinity is often contrasted with more ambivalent versions of masculinity. In fairy tales the construction of heroic masculinity is centrally conveyed through the ability for the Prince to rescue the Princess as the entrée to 'live happily ever after.' Relatedly, this leads the chapter into an exploration of romantic discourses. Romance, heroic masculinity, and the clash between 'good' and 'bad' femininity are all themes that previous research about fairy tales has explored extensively, and the chapter concludes with a brief review of this research.

\section{Early to Mid 20 ${ }^{\text {th }}$ Century Femininities}

Late $19^{\text {th }}$ to early $20^{\text {th }}$ century media representations of femininity were primarily defined by traditional discourses of femininity that construct women as caring, domestic and nurturing (Cancian \& Gordon, 1988). However, the turn of the century was also a time period where women were beginning to enjoy increased freedoms due 
to the suffrage movement. Cancian and Ross (1981), for example, found that coverage of the suffrage movement in The New York Times and The Reader's Guide mirrored the strength of the movement, which they claim may have resulted in a "multiplier effect," where coverage was subsequently increased as audiences became more concerned with these issues (p.15). This illustrates the complex relationship between media and society; that media is not merely a reflection of societal concerns, but can also evolve in line with dominant concerns of society. Despite the advances made by the suffrage movement, traditional discourses remained pervasive in the media construction of idealised femininity. Such was the case in Cancian and Gordon's (1988) discursive examination of marriage advice in magazines wherein at the beginning of the 1900's, women were expected to suppress their negative emotions in order to maintain their marriage. Being 'sweet' and 'nice' was thus central to these early representations of idealised femininity.

The 1930s were similarly characterised by traditional discourses of femininity that idealised motherhood and passivity, and these ideologies underpinned media representations of femininity of the time (Cancian \& Gordon, 1988; Flamiano, 2000). Although the 1920's era was defined by the emergence of 'new' femininities such as 'flappers,' the freedoms that women had enjoyed were withdrawn when the First World War concluded (Cancian \& Ross, 1981). The focus on maternalism during this social context is illustrated by Flamiano's discursive analysis of the discourses that operated in relation to contraception advice in women's magazines from 1938-1969. In the 1930s, there was a low coverage of birth control as these periods were characterised by a privileging of maternalism in contrast to World War One, where the emphasis on motherhood was lessened. Cancian and Gordon also found that emotion norms during this time period centred on maintaining harmony, linking this to a social context where 
the Great Depression produced few employment opportunities for men and conflict was easily able to arise.

In the 1950's, the social climate was also defined by traditionalism (Gauntlett, 2002). Gauntlett's brief review of films from the 1950s to 2000 indicates that cinematic representations of gender have undergone significant shifts in relation to the sociohistorical context. He notes, for example that films produced in the 1950s and 1960s predominantly featured men dictating the action, while the women were cast as romantic interests needing to be rescued. This reflected the broader context where traditional discourses prevailed, prizing men's role as providers and women's role as nurturers and homemakers (Loke \& Harp, 2010). Content analysis of media produced within the 1950s found that in comparison to during the war, there was a decline in representations of women's issues during this period (Cancian \& Ross, 1981), increased disparity between male and female characters in children's books (McCabe, Fairchild, Grauerholz, Pescosolido, \& Tope, 2011), and a shift to more conservative values being espoused in Seventeen magazine, such as an increased focus on the domestic sphere (Loke \& Harp, 2010). Lakner and Paff's (1997) analysis of dress in magazine ads also observed that following World War Two, there was more discrepancy in the manner in which the men and women dressed, which coincided with a social context where gender roles were also more defined. Discourse analysis of media constructions of idealised femininity in the 1950s has also been employed (Cancian \& Gordon, 1988; Flamiano, 2000). Congruent with their observations for the 1930s, Cancian and Gordon (1988) noted more traditional marriage advice being articulated in women's magazines. Flamiano (2000) also observed a 'post-war maternal ideology' that produced a renewed interest in reproduction as the key to rebuilding society.

\section{0s to 1980's - Feminism and Media Femininities}


Much of the late 1960 - 1970's was dominated by significant socio-political movements, which had some impact on media representations of women. The proliferation of feminist thought and activity from the late 60 s underlined debates about the restrictive stereotypes of women that were circulated in the media (Gill, 2007). According to Gauntlett (2002), the 'swinging sixties' provided less restrictions for women, particularly concerning sexuality. However, Gauntlett's review of media in this time period indicates that traditional discourses of femininity still underpinned media representations of femininity in a similar fashion to the 1950s. In films and advertising, the women were predominantly depicted as passive, domestic and romantic. Similarly, the image of the 'happy housewife,' whose only concern was marriage, continued to dominate the magazine genre. Although the magazine genre was still mainly traditional, Gauntlett claims that it was the most rapidly evolving media form to cater to more 'liberated' women. With its target market of young and independent women, Cosmopolitan was launched in 1964. In 1965 Helen Gurley Brown became the editor in-chief, and was particularly concerned with promoting sexual assertiveness as central to being a modern woman (Scanlon, 2009).

In the 1970 s, the increasing popularity of feminism was accompanied by significant changes in the media landscape. According to Lotz (2001), the 1970s saw an increase in the number of women working outside the home, which was accompanied by an increase in television and advertising content employing feminist ideas. Lotz claims that this was attributed to the economic benefits associated with targeting women workers as consumers. Dow's (1990) examination of The Mary Tyler Moore Show $(1970$ - 1977) demonstrate the shifts in the dominant representations of femininity noted by Lotz. The character of Mary was revolutionary due to her satisfaction with being single and working despite being in her thirties. However, Dow highlights how Mary's femininity was reassured through the depiction of her as a 'daughter' and 
'mother' to her co-workers. In this sense there was a persistent emphasis on traditional representations of femininity despite the transformations to that were occurring in society. Gauntlett's (2002) review of media in this time period further supports the account of intersecting traditional and more contemporary discourses of femininity. $\mathrm{He}$ notes that women in film were gradually gaining more empowerment. Using Star Wars (1997) to illustrate, he notes that although Princess Leia is provided with fighting skills, she is still in a sense a 'damsel in distress' needing men to rescue her.

In the 1980s media representations began to be increasingly complex (Gill, 2007). The 80 s saw an increase in the representation "tough, power-dressed, successful women," although there was a simultaneous backlash to this increased independence (Moseley \& Read, 2002, p. 238). Gauntlett (2002) remarked that Ripley in Alien (1986) was more physically capable than Ripley in Alien (1979). Although the trend of representing women in the workforce was persistent, it was accompanied by 'backlash' texts such as Fatal Attraction (1987) (Lotz, 2001). Lotz also remarks how this time period was characterised by concerns that feminism and having a family is incompatible, fears that were accompanied by texts with imagery such as biological clock metaphors.

\section{0s to 2000's - Postfeminist Femininities}

Within late capitalist society neoliberalism proliferates through social policies that provide less support from the state, instead placing responsibility upon the individual to manage their lives (Gonick, 2006; Harris, 2004b). North America in particular gradually adopted a host of social policies that functioned to reduce support for welfare and education (Gonick, 2006). Neoliberalism constructs the individual as responsible for managing every aspect of their lives, with pressure residing from within the individual rather than external sources (Gill, 2007, 2008). For example, analysis of 
weight loss television shows such as The Biggest Loser (2004 - present), has identified how neoliberal discourses are mobilised through associating fatness with a failure to effectively regulate oneself (Sender \& Sullivan, 2008). As Sender and Sullivan put it, the "neoliberal moment that demands self-disciplined, self-directed, willing citizens both produces and requires their nemesis: the undisciplined, food-addicted, lazy fatty" (p. 580). As the social context has shifted to be more focused on the individual as responsible for managing their lives, idealised versions of femininity have also undergone significant transformations.

Gill (2007) outlines how postfeminism is a 'sensibility' that, borrowing from neoliberalism, relies heavily on self-surveillance. She argues that while surveillance of one's appearance has persistently been an aspect of femininity, the focus has arguably intensified in contemporary late modern times where regulating one's appearance through means such as dieting, exercise and even cosmetic surgery is represented as voluntary and even as pleasurable (Fairclough, 2012; Gill, 2008). This regulation is exemplified by the popularity of the makeover paradigm, where every area of a woman's life is carefully scrutinised and improved (Gill, 2007; McRobbie, 2009). Makeover television is not merely concerned with women's appearance, but other aspects of their lives as well, such as their relationships and their interior decorating. An illustration of this makeover paradigm is the reality show Tough Love (2009-present); where female contestants are instructed to change their behaviour and appearance in order to be rewarded with a heterosexual partner. In particular, it is primarily women who are hailed through the makeover and the discourse of self-surveillance through which it is constructed. Whereas the men in Tough Love are considered adequate, the women are propelled to scrutinize every potential flaw in themselves and each other. In this sense, ideal femininity is no longer confined to excelling within the domestic 
sphere, but also includes the ability to carefully regulate oneself in addition to having a beautiful, heterosexually desirable body (Gill, 2007).

Girl power is a dominant media discourse through which younger female audiences are hailed within this postfeminist, neoliberalist context (Gill, 2007; Gonick, 2006; Griffin, 2004; Hains, 2007; McRobbie, 2009). In line with neoliberalism's emphasis on individual effort, girl power provides girls with the impression that they are capable of achieving anything they set their minds to (Gonick, 2006). The concept of girl power is in and of itself postfeminist, in that it takes equality for granted, yet simultaneously presents feminism as outdated (Griffin, 2004). The girl power movement originated at the start of the 1990s with the zine movement Riot Grrrls (Gonick, 2006; Hains, 2007). The movement was renowned for incorporating girlishness with "all that is most threatening in a female adult: rage, bitterness, and political acuity" (Gonick, 2006, p. 7). However, Gonick chronicles how the advent of the girl power movement as a radical form of rebellion against normative femininity was transformed into a less politicised, consumerist rhetoric. This began with the girl power rhetoric being rapidly appropriated by female musicians such as the Spice Girls (Gonick, 2006; Griffin, 2004). This popularity of girl power in music was accompanied by a proliferation of merchandise brandishing phrases such as "girls rule." Television shows such as Buffy the Vampire Slayer (1997- 2003) and The Powerpuff Girls (1998 2004) also adopted the ethos that 'girls can do anything' (Gonick, 2006; Hains, 2007).

A decade later, girl power continues to underpin media representations of girls and women. Feminist research has heralded Katniss from the book series The Hunger Games (2008-2010) as a female character that adheres to the concept of girl power (Taber, Woloshyn, \& Lane, 2013). The popularity of this strong, independent female character with female audiences (Firestone, 2012; Taber et al., 2013; Woloshyn, Taber, 
\& Lane, 2013) is likely to be involved in the popularity of the book's subsequent cinematic adaptations (2012 - 2014). Through her hunting, fighting and disavowal of being the 'damsel in distress,' Katniss' behaviour positions her within these girl power discourses (Taber et al., 2013).The character Emily in the Television series Revenge (2011 - present) is a further example of the media adoption of the girl power rhetoric. Throughout the series, Emily 'saves herself,' and uses violence to achieve her goals, physically overpowering men on numerous occasions. Contemporary cinematic renditions of fairy tales also draw on these girl power discourses. An illustration of this is the film Hansel and Gretel: Witch Hunters (2013), where Gretel fights alongside her brother to brutally kill witches. Central to the representation of these 'strong females' is their fighting and leadership abilities, behaviour traditionally associated with hegemonic masculinity (Connell \& Messerschmidt, 2005; Day, Gough, \& McFadden, 2003; Lee, 2013; Taber et al., 2013; Woodward, 2000). By engaging in physical violence, these girl power icons are able to transgress the traditional fairy tale narratives that positions the male characters as heroic saviours, while the women are represented as 'damsels in distress' incapable of violence (Woloshyn et al., 2013).

Central to this construction of the ideal girl power subject is the combination of this overpowering strength and tenacity with a conventionally feminine physique (Hains, 2007; Harris, 2004b; Willis, 2009). While early girl power icons such as Buffy and the Powerpuff Girls were physically strong, easily overpowering men, their appearance provided a reassurance of their femininity (Hains, 2007). This representation is congruent with the current representations of girl power icons (Taber et al., 2013). Taber et al., for example, found that the girls in their study wanted Katniss to "to uphold in her image as an attractive character with girl power" (p.1034). Media representations of young women as 'strong' and 'beautiful' have been subject to both critique and praise (Gonick, 2006; Hains, 2007). They have been critiqued for providing a version of 
femininity that is unattainable for many girls; for example, being a powerful fighter capable of slaying grown men is not always a reality for many girls (Gonick, 2006; Hains, 2007; Willis, 2009). However, it has also been praised for empowering girls by instructing them that they can be strong, violent and powerful whilst still retaining a conventionally attractive, feminine aesthetic. Rather than constructing girls as fragile, victimised and in need of protection, the discourse recognises their strength and independence (Gonick, 2006; Hains, 2007). However, according to Harris (2004a), girl power is a discourse rife with contradictions. While it constructs female solidarity as more important than heterosexual relationships, being sexually attractive to the opposite sex remains important. Thus, in this postfeminist context, ideas of independence and girl power coexist with the privileging of traditional aspirations such as marriage (Gill, 2007).

In contemporary Western society, girls and women are instructed that they have limitless opportunities, although traditional discourses of femininity continue to operate simultaneously (Charlton, 2007; Gill, 2007; McRobbie, 2009). In this sense, contemporary girl power discourses privileging 'toughness,' strength and leadership abilities (Harris, 2004b; Inness, 2004; Lee, 2013) are regulated by traditional constructions of 'good' femininity centring on 'niceness' (Walkerdine, 1990), virtue (Charlton, 2007), and an affinity for the domestic sphere (Skeggs, 1997). McRobbie (2004) refers to this coexistence of traditional and contemporary discourses as the “double entanglement." She highlights how Bridget Jones is a character that exemplifies these co-existing contradictory discourses. McRobbie contends that Bridget is the "product of modernity" through her education, career, and self- surveillance, although she simultaneously aspires to have a traditional 'White Wedding' (p.261). McRobbie claims that this indicates that whilst feminist achievements such as having a career are taken for granted, they are simultaneously denigrated through presenting tradition as 
desirable. The television series Ally Mcbeal (1997 - 2002) has also been subject to substantial academic critique for its depiction of Ally as an independent career woman who is still constrained by her desire for fulfilment through heterosexual companionship (Moseley \& Read, 2002). Through this complex entanglement of contradictory discourses, idealised femininity is produced. However, there is also a concurrent fear of 'failure' and being rendered a 'bad woman'(Gill, 2008).

\section{Polarities: Good vs Bad Versions of Femininity in Media}

Media representations of femininity are often defined by the polarity between 'good' and 'bad' versions of femininity (Charlton, 2007; Griffin, 2004; Harris, 2004a; Ussher, 1997; Walkerdine, 1990). Research has examined the traditional discourses of femininity that underpin media representations of 'good femininity.' For example, Walkerdine's analysis of girl's comics Bunty and Tracy found that the 'good' female characters were defined by their passivity and resignation to their circumstances. The heroines did not display anger or jealousy, but continued to suffer and help others.

Being maternal and 'caring' is also central to being positioned within traditional discourses of femininity (Skeggs, 1997; Ussher, 1997). Skeggs' research on workingclass women's attendance of domestic courses chronicles how the courses formed an association between motherhood, femininity and caring to construct the ideal feminine subject. Similarly, Ussher (1997) provides a description how 'good' femininity is rooted in the conception of the 'Madonna' that was popularised in pre-Renaissance European art, represented as the Virgin Mary with the baby Jesus or simply a woman with her child. Later in films, the idealisation of the Madonna persisted, privileging the maternal and domestic as central to prevailing discourses of femininity (Ussher, 1997).

\section{Whereas traditional discourses of femininity glorify motherhood, 'bad} femininity' is defined by a disavowal of motherhood (Aguiar, 2001; Bromley \& Hewitt, 
1992; Chamberlain, 2005). Media representations of villains are often defined by their lack of maternal instincts, such as the classic character of Lady Macbeth (Aguiar, 2001; Chamberlain, 2005) and later the character of Alex in Fatal Attraction (1987). Whilst 'good' femininity is defined by a resignation to circumstances (Walkerdine, 1990), 'bad' femininity is often defined by ambition (Aguiar, 2001; Radway, 1981). For example, Radway's (1981) examination of Gothic Romances found that the villains were characterised by their excessive ambition and sexuality.

Sexuality is a central aspect of the divergence between 'good' and 'bad' femininity (Charlton, 2007; Griffin, 2004; Radway, 1981; Reay, 2001). This is illustrated by Reay's (2001) study of the 'good' and 'bad' peer groups that young girls form. In contrast to the participants who identified themselves as 'Nice Girls,' the 'Spice Girls' gained empowerment from their sexuality, although "as sexual little women, they occupy a space where they can be bad" (p.161).The link between displays of sexuality and transgression has also been examined in relation to quizzes in girl's magazines (Ostermann \& Keller-Cohen, 1998). Ostermann and Keller-Cohen contend that quizzes serve as a Foucauldian form of 'discipline' that 'punishes' girls for displays of behaviour that runs contrary to the characterisation of the 'good girl.' An illustration of this is that if a girl flirts excessively, she is negatively evaluated by the quiz as a 'Wild Woman,' while the 'Great Girlfriend" is defined as "flirtatious in a subtle, nonintimidating, and no-pressure way" (p.543). However, a lack of flirtation abilities earns girls the label of 'Snob Sista' or 'A Great Pal.' They highlight how this produces only one type of 'good girl' who carefully utilises her sexuality, but several versions of the 'bad girl' that are either excessively sexual or 'prudish.' Similarly, Griffin's (2004) analysis of Mad About Boys magazine found that the quizzes constructed the ideal girl power subject as able to carefully negotiate maintaining heterosexual relationships with independence and female friendships. Although being excessively involved with the 
opposite sex was denigrated, a complete disavowal of sexuality was also negatively constructed. This is noteworthy in light of the current postfeminist social climate where sexual empowerment is constructed as key to femininity (Gill, 2007; McRobbie, 2009). However, the vilification of an excessive reliance on one's sexuality remains persistent, as demonstrated in these analyses of quizzes (Griffin, 2004; Ostermann \& KellerCohen, 1998).

The dichotomy between 'good' and 'bad' has potential implications for the construction of subjectivities. According to Ostermann and Keller-Cohen (1998) "the very concept of dichotomy is at the centre of patriarchy. Whereas the female world is constantly dichotomised, hegemonic masculinity is naturalised" (p.550). They claim that these evaluations of female behaviour propel girls and women to constantly evaluate themselves in an attempt to be 'good.' The complexity of achieving an ideal version of femininity is highlighted by Reay (2001). Although the 'Nice Girls' in the study were praised by their teachers for their work ethic, Reay comments they "exemplify the constraints of a gendered and classed discourse which afforded them the benefits of culture, taste and cleverness but little freedom" (p.158). Moreover, although these 'good' girls were rewarded for their behaviour, they were simultaneously deemed 'boring' by their peers and were driven to constantly monitor their behaviour.

\section{Masculinities}

Constructions of femininity are often not only defined by the polarity between 'good' and 'bad' femininity, but also by their opposition to masculinity. For example, 'good' women are often constructed as passive and confined to the private realm, whereas idealised masculinity is defined by activity and a presence in the public sphere (Ashcraft \& Flores, 2003). The concept of hegemonic masculinity provides an important basis for understanding the discursive constructions of masculinity in the 
media. Connell and Messerschmidt (2005) have studied the concept of hegemonic masculinity extensively, claiming it is associated with representations of men as independent, heterosexual, physically capable, staunch and heroic. They also claim that the notion of hegemonic masculinity entails the naturalising of women as holding inferior power to men. Furthermore, they explain that hegemonic constructions of masculinity do not necessarily bear any resemblance to reality, instead serving as an aspirational ideal that men are aware that they will not reach.

While there are continuities with the media representation of masculinity across historical periods, there are also divergences (Ashcraft \& Flores, 2003; Hatfield, 2010; Loke \& Harp, 2010). As Ashcraft and Flores explain, "masculinity is not a stable or unified phenomenon; its meanings shift over time in relation to culture, context or person" (p.3). Like femininity, then, the broader social climate is a crucial aspect of analysing prevailing discourses of masculinity in the media. For example, Hatfield claims that prior to the $1950 \mathrm{~s}$, the breadwinner version of masculinity was the most idealised. However, after the 50's there was also an increase in the emphasis on values such as independence and hedonism, in part spurred on by the arrival of magazines such as Playboy. Loke and Harp's discursive analysis of masculinity in Seventeen from 1945-1955 and 1995-2005 supported the notion that dominant versions of masculinity transform in line with the social context. They claim that while boys were initially constructed as 'intelligent' and 'successful,' they were constructed as more 'foolish' and 'sex obsessed' in the later editions. This indicates that while there are continuities in the prevailing discourses of masculinity, certain versions of masculinity are more popularised and prolific in a particular time period.

Heroic masculinity is one such version that has at times enjoyed unrivalled popularity in the media (Benwell, 2004; Connell \& Messerschmidt, 2005; Holt \& 
Thompson, 2004; Kipnis, 1994; Sparks, 1996; Wetherell \& Edley, 1999). Benwell (2004) describes heroic masculinity as a tendency to be "active, rational, professional, autonomous, knowledgeable, and authoritative" (p.14). However, she claims that physicality is the predominant means through which heroic masculinity is represented. This physicality can either be bodily or action-orientated. Sparks' (1996) analysis of masculinity in Hollywood blockbusters found that there was a pervasive interest in heroic masculinity. However, the recent 'crisis in masculinity' has produced an intensification of interest in leading men displaying heroic masculinity (Sparks, 1996). This 'crisis in masculinity' is considered to have arisen from an increased feminisation of labour (Ashcraft \& Flores, 2003; Holt \& Thompson, 2004). As society has shifted from being based on production to being more centred on consumerism, there is a growing disillusion amongst men about their function in modern society (Faludi, 1999). While heroic masculinity may be particularly glorified in the current social context due to this 'crisis in masculinity' (Sparks, 1996), heroism has been a pervasive element of masculinity over time (Benwell, 2004; Connell \& Messerschmidt, 2005; Holt \& Thompson, 2004; Kipnis, 1994; Sparks, 1996; Wetherell \& Edley, 1999). The centrality of heroic masculinity in fairy tales is of particular interest to the current project due to the classic narrative of the 'damsel in distress' being rescued by her Prince.

Although heroic masculinity has enduring appeal in the current social climate, it is often juxtaposed with more ambivalent versions of masculinity (Ashcraft \& Flores, 2003; Benwell, 2004; Taber et al., 2013; Woloshyn et al., 2013). An example of this is The Hunger Games trilogy, where the character of Gale represents a hegemonic version of masculinity through his strength and affinity for violence, while the character of Peeta is constructed in line with more marginalised discourses of masculinity (Taber et al., 2013; Woloshyn et al., 2013). In Taber et al.'s audience study on The Hunger Games, viewers perceived Peeta to be excessively 'girlish' for his disavowal of violence 
and not fulfilling the role of hunter and protector. Similarly, Hatfield's (2010) narrative thematic analysis of Two and a Half Men noted the contrast between Charlie's dominant masculinity and Alan's subordinate masculinity. Whereas Charlie is defined by his financial security, heterosexuality, independence and drinking, Alan's characterisation as the sensitive, domestic 'new man' is derided. These analyses of media representations of masculinity indicate that while ambivalent versions of masculinity have begun to co-exist with hegemonic versions, the traditional, heroic versions of masculinity continue to hold considerable social power.

\section{Masculinity, Femininity and Romance}

The concept of heroic masculinity is also central to prevailing romantic discourses, particularly, as noted earlier, in relation to the classic 'damsel in distress' narrative where the hero's love overcomes all obstacles (Stacey \& Pearce, 1995). Despite the proliferation of 'newer' versions of femininity, the societal significance of romantic discourse is enduring (Jackson, 1995; Stacey \& Pearce, 1995). The romantic discourse is central to the construction of subjectivities, and is impossible to entirely escape (Gill, 2007; Jackson, 1995; Stacey \& Pearce, 1995). Media such as magazines, books, films and songs are all saturated with romantic narratives. For example, McRobbie's (1991) analysis of Jackie magazine and Walkerdine's (1990) examination girl's comics both found that romance was presented as the most central aspect of a girl's life. The classic romantic narratives that are espoused in a variety of media traditionally involve an initial meeting where the characters 'fall in love.' Although they are then faced with obstacles, they are eventually reunited, with 'love conquering all' (Radway, 1981; Stacey \& Pearce, 1995). According to Stacey and Pearce (1995), romance is best understood as a discourse, as there is not one universal conception of romance. Rather, romantic discourses are subject to the processes of power and 
knowledge and are not unified and stable, but rife with contradictions and constantly transformed. Despite the persistence of this fascination with romance, romantic discourses are continuously transformed in line with the social context (Gill, 2007; Stacey \& Pearce, 1995). As Stacey and Pearce (1995) explain, "to invoke the metaphor of the virus, it is its capacity for mutation which has enabled romance to survive" (p.12). The fluidity of romantic discourses is illustrated by Cancian and Gordon's (1988) examination of romantic discourses in women's magazines. They claim that at the start of the $19^{\text {th }}$ century, there was a belief that love was able to "thrive spontaneously with minimal caretaking” (p.315). However, during the war, the articles encouraged a less idealistic perspective on love. This illustrates the way in which romantic discourses are specific to socio historical contexts.

Drawing on Giddens (1992), Stacey and Pearce (1995) explain how the current social climate's focus on individualism has also transformed dominant romantic discourses. In line with the "self-reflexivity of modernity," people are required to look inwards more to examine their feelings towards the object of their affections and their perceptions of their own assets and flaws (p.35). Stacey and Pearce argue that due to the proliferation of feminism and the changing structure of the labour market, romance is not intrinsically linked with having children and being in a monogamous relationship, producing less focus on idealised 'happily ever after' relationships that result in marriage. The focus is more on a relationship "for its own sake" rather than "kinship, reproduction or marriage" (p.35). Women are not content with unsatisfying marriages, and are "challenging men, making demands on them and ultimately leaving them" (p.36). Thus, rather than serving a utilitarian purpose, romance is appreciated in its own right. 
Contrastingly, Gill (2007) and McRobbie (2009) claim that the current social climate has produced a renewed fascination with the traditional romantic narrative. Although heterosexual partnerships have less material gains than in earlier time periods where women were dependent on marriage for financial security (Stacey \& Pearce, 1995), Gill argues that romance still serves as a form of 'security.' While women are endowed with new freedoms, they still seek the traditional 'fairy tale romance.' This is illustrated by reality television shows such as The Bachelor (2002- present), where constant references are made to the contestants' desires for their 'fairy tale romance' (Dubrofsky, 2006). While such shows are evidently highly artificial, they nevertheless perpetuate the notion that women wish to position themselves within these classic romantic narratives (Dubrofsky, 2006). In the immensely popular Twilight series, romance is also constructed as the primary means to achieving fulfilment (Taylor, 2012). Although media such as The Bachelor and Twilight has been criticised for espousing outdated and excessively traditional romantic narratives (Dubrofsky, 2006; Taylor, 2012) the 'happily ever after' narrative also underpins media that is otherwise 'feminist' in its construction of female characters (Firestone, 2012; Taber et al., 2013; Woloshyn et al., 2013). As Woloshyn et al. point out, in The Hunger Games, the character of Katniss does not consider romance to be a central concern in her life. However, she has two suitors, eventually marrying and having children with one of them.

\section{Fairy Tale Research}

The endurance of the 'fairy tale romance' is particularly relevant in relation to the current project. Fairy tales are recognisably texts saturated with romantic narratives (Rowe, 1979), which are heavily gendered and feminised (Jorgensen, 2012). Ussher (1997) highlights how in fairy tales, the narrative of 'some day my prince will come' is 
particularly salient. Men thereby serve as the ultimate salvation from a life that is otherwise confined to drudgery. This idealised version of romance is only available to the 'good' girls, mobilising a moral discourse that only rewards certain versions of femininity.

Critical feminist analysis of fairy tales have highlighted how representations of femininity are defined by the clash between 'good' and 'bad' femininity (Atkins, 2005; Bacchilega, 1993; Fisher \& Silber, 2000; Harries, 2000; Joosen, 2004; Jorgensen, 2013; Rowe, 1979). The 'good' heroines have been critiqued for being passive 'damsels in distress' with limited abilities to exert any real change (Bacchilega, 1993; Jorgensen, 2013; Rowe, 1979). Regardless of the torment they are subjected to, they continue to endure hardship without voicing their concerns (Bacchilega, 1993; Jorgensen, 2013; Rowe, 1979). In spite of their miserable circumstances, their natural beauty and virtue continues to shine through. They are competent within the domestic sphere, excelling at tasks such as preparing a meal and cleaning (Rowe, 1979). Eventually, due to their boundless goodness, caring, and self- sacrifice, they are rewarded with the love of a handsome, rich Prince (Rowe, 1979). A moral discourse is invoked, where women who do not adhere to these prescriptions of idealised femininity are severely punished (Jorgensen, 2013; Rowe, 1979). In stark contrast to the passivity of the heroines, the villains are vain, selfish, and fiercely ambitious. Whereas the heroines receive their 'happily ever after,' the villainous women are often brutally executed (Jorgensen, 2013; Rowe, 1979).

Beyond the research utilising feminist critique, a small body of research employing content and discursive analysis has explored how gender constructions in fairy tale texts relate to the social context they are produced in. This work has identified pervasive themes within fairy tales. Grauerholz and Baker-Sperry (2003) explored the 
theme of beauty across written, film and video reproductions of fairy tales from the original Grimm versions to the current reproductions using content analysis. They found that the emphasis on beauty increased at the end of the twentieth century and is predominantly connected with virtue and youth. Through discursive analysis, they concluded that the tales were "powerfully responsive to social change and not simply in a way that mirrors society" (Baker-Sperry \& Grauerholz, 2003, p.714). They considered the idealization of beauty as a form of "normative social control" that served to place restrictions upon women's lives in order to maintain a "gender system" (p.711). The authors claimed that as women were bound by fewer external restrictions through means such as increased employment opportunities, there was an increased reliance on internal forms of social control through the emphasis on beauty. This serves to further highlight the pivotal role of social context and has relevance to the postfeminist intensification of the value of beauty in the $21^{\text {st }}$ century (Gill, 2007). Jorgensen's (2012) content and discursive analysis examining the representation of the body across fairy tales provided further evidence of the pervasiveness of the beauty ideal in fairytales. Although the studies cited above have been effective in terms of identifying persistent themes, they ignore the manner in which specific social contexts are implicated in the constructions of the gendered discourses found.

As the research reviewed above suggests, discourses of femininity are dynamic and intertwine with the social environment within which they are produced (Gill, 2007). Some scholars have employed a discursive, feminist perspective in order to address how original texts have evolved according to shifts in gendered norms (Joosen, 2004; Parsons, 2004). Joosen's analysis of the original Snow White and feminist retellings in the 1970s and 1980s highlighted the manner in which the later adaptations responded to feminist critique of the original tales. However, feminist texts that are not 'popular' in terms of box-office sales were relied upon, which may limit observations about broader 
societal shifts. Parsons compared the original version of Cinderella with two contemporary feminist written retellings in the late 1990s. She discovered that the revisions contained narratives that made more diverse subjectivities available to the audiences, for example focusing on independence for the heroine and problematizing issues such as beauty and marriage. Parsons' and Joosen's work is noteworthy, as it emphasises how the reproductions are influenced by feminist perspectives, although neither author elaborates on how these fairy tales are connected to broader discourses within society. Of particular relevance, Parson's exclusion of broader sociocultural discourses missed the opportunity to consider Cinderella within a postfeminist context. The proposed research seeks to extend Parsons' and Joosen's research through a specific focus on the ways in which contemporary revisions may draw upon a postfeminist context. Reviewing Parsons' and Joosen's research illustrates that while comparisons of original tales with contemporary remakes is important, examining the texts in relation to context would provide a more thorough examination of the constructions of gender within society.

According to the poststructuralist perspective, dominant discourses of gender are fluid and respond to the social and political context they are embedded within (Stainton Rogers \& Stainton Rogers, 2001). A limited proportion of research on fairy tales has examined how dominant discourses within society are incorporated and resisted in the reproductions of fairy tale texts within that era (Rothschild, 2010). Rothschild conducted a critical analysis of written and cinematic reproductions of fairy tales in relation to waves of feminism. Rothschild claims that texts were powerfully responsive to societal changes by mirroring feminist concerns. However, she also highlights that Disney Princess films such as Snow White and the Seven Dwarfs (1937) served to regulate the advances made by the feminist movement by presenting traditional femininity as desirable. Such research demonstrates the importance of considering the 
complex relationship between the social climate and the texts produced within it. However, Rothschild's decision to choose diverse texts from each era limits the ability to draw inferences about the progression of a particular tale. The current research addressed this limitation by focusing on the progression of one text.

Specifically, this thesis examines the gendered discourse within six film renditions of Grimm's (1819) Snow White from 1916 to 2012 using Foucauldian genealogical discourse analysis. While the Disney version of Snow White and the Seven Dwarfs (1937) has been subject to academic investigation (Craven, 2002; Rothschild, 2010), research has not yet been directed at examining the progression of the constructions of masculinity and femininity within film reproduction of the tale. Whereas previous research has examined fairytales in relation to social context (eg. Rothschild, 2010), the current research seeks to extend the existing body of literature through situating the analysis in a postfeminist context. The following analysis seeks to identify discourses of masculinity and femininity within each version of the tale and to examine continuities and divergences of gender constructions over time. Furthermore, the current research seeks to explore the relationship between the socio-historical context of the era within which the film was produced and the gendered subjectivities made available in the texts.

\section{Organisation of this Thesis}

The following chapter of this thesis (Chapter Two) addresses the methodological framework and the analytical process and will provides a brief description of the films that were analysed. The analysis is divided into two chapters: Chapter Three is concerned with analysis of the early films (1916, 1937, and 1959) and Chapter Four analyses the later films (both produced in 2012). These chapters examine the discourses employed by the films to construct the main characters. The chapters will also highlight 
how these discourses are situated in the broader social and historical context related to the year of the film's production. Chapter Five will provide a synthesis of these two analytical chapters, teasing out the continuities and divergences in the discourses and the gendered subjectivities each of the films make available. Of particular interest is also how these discourses have evolved in line with their social context. The chapter will also discuss limitations, implications, and potential future research directions. 


\section{CHAPTER TWO}

\section{METHODOLOGY}

\section{Overview of Chapter Contents}

This chapter presents a description of the texts chosen for analysis and addresses the methodological framework and the method of analysis. The methodology section considers the feminist poststructuralist framework of the study, focusing on language and subjectivity as its central tenets. The analytical section details the approaches taken to data analysis: thematic analysis and Foucauldian discourse analysis. The final section of the methodology addresses reflexivity, providing an account of my own stance towards, and experiences in the research topic.

\section{Description of Films}

The criteria required that the films were in English, full-length and 'popular' based on box office sales. Films that were brought out straight to DVD were excluded. From the 24 remakes, the films that met the inclusion criteria were Snow White (Dawley, 1916), Disney's Snow White and the Seven Dwarfs (Cottrell, 1937), Snow White and the Three Stooges (Lang, 1959), Mirror, Mirror (Singh, 2012) and Snow White and the Huntsman (Sanders, 2012). The three early films were primarily targeted at children and Mirror, Mirror was also targeted at a young audience, but Snow White and the Huntsman was targeted at an older audience.

Snow White tells the tale of Snow White, a beautiful young Princess forced to work as a scullery maid by her evil stepmother after her parents die. When the evil Queen is informed by her Magic Mirror that Snow is now the "fairest of them all," she is overcome be jealousy and orders the Huntsman to kill her. He is unwilling to kill her, 
abandoning her in the forest. A bird shows her to the Dwarves' cottage. After she meticulously cleans the house and cooks dinner, the Dwarves return. Impressed by her domestic competency, they allow her to remain in the house. When the Queen is informed that Snow is still alive, she appears at the cottage disguised as an old hag and deceives Snow into trying on a poisoned comb, although the Dwarves save her. The Queen then returns disguised as a pieman, giving her a poisoned apple which makes her appear dead. When the Prince returns her to the Queen, the apple is dislodged and she awakens to become crowned Queen.

Disney's production of Snow White and the Seven Dwarfs follows a similar narrative to the 1916 version, although Snow is only given the poisoned apple. She awakens when the Prince kisses her, who then takes her away to live with him in the castle.

Snow White and the Three Stooges follows the same plot of Snow being abandoned in the forest after her stepmother's attempt to have her killed. However, instead of encountering the Dwarves, she meets the Three Stooges. They are accompanied by the Prince, although he is not aware of being of royal descent. The Prince is kidnapped by the Queen and endures a fall that is thought to have killed him. The Queen transforms herself into a witch and gives Snow a poisoned apple. When the Prince awakens from the fall, he realises he is the Prince, saving Snow by kissing her and then marrying her.

In Mirror, Mirror, Snow has been left in the care of her stepmother, who is obsessed with maintaining her appearance and being deemed the "fairest of them all" by her Magic Mirror. The Queen decides to throw a ball to entice a rich, young Prince. However, he is captivated by Snow instead. Gripped by jealousy, the Queen casts Snow into the forest. She finds refuge with the Dwarves, who teach her to fight in exchange 
for her cooking them all meals. The Queen then seeks to capture the Prince's affection by giving him a "puppy love potion" which makes him enamoured with her. After overcoming the Queen's attempt to kill them, Snow and the Dwarves attempt to interrupt the Queen's wedding to the Prince. Snow's kiss breaks the spell, and they subsequently get married. At the wedding, the Queen returns disguised as a hag and gives Snow a poisoned apple. However, Snow refuses the gift and lives 'happily ever after' with her Prince.

Although Snow White and the Huntsman has similarities to the earlier versions, there are many additional elements to the plot. After killing the King, the kingdom is ruled by the Queen, who retains her beauty and power through draining the youth from young girls. Snow White is confined to a prison cell, but escapes into the forest. The Huntsman is sent to bring back Snow's heart for the Queen to consume. They both seek refuge in a village where the women have scarred their own faces in order to evade the Queen. The Huntsman gradually falls in love with Snow. Snow's childhood friend, William, is also in love with her and seeks to rescue her. Snow and the Huntsman are then joined by the Dwarves and William. Disguised as William, the Queen tempts Snow into eating a poisoned apple which renders her comatose. Although she is first kissed by William, it is when the Huntsman later kisses her that she finally awakens. Snow and her army then return and successfully save the kingdom from the Queen, and Snow is crowned Queen.

\section{Methodological Framework}

Feminist poststructuralism emerged as a perspective that specifically aligns feminism with poststructuralism, rather than considering them two dichotomous perspectives (Gavey, 1989). In line with poststructuralism, feminist poststructuralism is concerned with challenging positivist, scientific notions and posing "questions that 
could take us beyond the surface of our culturally shared commonsense understandings of the world" (Gavey, 2011, p. 184). Within the scientific disciplines, structuralist approaches are most commonly used. Structuralism claims that it is feasible to systematically quantify knowledge and that there is a "pre-existent, fixed, universal structure of reality" ready to be investigated (Gavey, 1989, p.463). In contrast, poststructuralism rejects the notion of the 'truth,' claiming there are multiple realities (Burr, 1995). Feminist scholars have supported this by highlighting that there are more diverse versions of reality than the dominant, patriarchal perspective (Gavey, 1989). For example, the dominant belief that women are biologically more suited to caring, nurturing occupations is problematized by feminist postructuralism (Weedon, 1997). Weedon explains that positivist perspectives such as evolutionary psychology claim that biological differences produce different skills for men and women. However, the conception of there being inherent differences between men and women "denies history and the possibility of change for the future," which are central aspects of poststructuralism (Weedon, 1997, p.3). According to poststructuralism, knowledge is produced through social relations and is constantly evolving. This perspective considers that it is not possible to draw universal claims, as knowledge is socially and historically specific. As knowledge is tied to systems of power, what is accepted as 'common sense' is thus influenced by these institutions (Weedon, 1997). This framework thus provides a "theoretical basis for analyzing the subjectivities of women and men in relation to language, other cultural practices, and the material conditions of our lives" (Gavey, 1989, p. 472). This allows for the emergence of alternative perspectives concerning the relationship between gender, knowledge, language and subjectivity. Feminist poststructuralism thereby seeks to understand the complex ways in which meaning is produced through considering the role of history and social relations (Weedon, 1997). The primary means of analysing how meaning is constructed is to examine language. 
The role of language is central to a poststructuralist theoretical framework (Weedon, 1997).Within mainstream psychology feminist approaches privilege women's experience and language is perceived as merely a reflection of experience (Gavey, 1989). In contrast, a feminist poststructuralist approach shifts away from the notion of experience as the primary source of meaning. Although it does not dismiss the importance of experience, it highlights that experience is intrinsically tied to language (Gavey, 1989). Weedon claims that "language is the place where actual and possible forms of social organization and their likely social and political consequences are defined and contested. Yet it is also the place where our sense of ourselves, our subjectivity, is constructed" (p.21).This highlights that language is a significant arena for the formation of meaning and is central to the production of subjectivity (Gavey, 1989; Hollway, 1989; Weedon, 1997).

According to Hollway (1989), subjectivity is concerned with "individuality and self-awareness - the condition of being a subject - but understand in this usage that subjects are dynamic and multiple, always positioned in relation to discourses and practises and produced by these - the condition of being subject" (p.25). Hollway also elaborates how subjectivities are created within social and historical relations, which allow the individual's sense of self to be fluid and responsive to change. This conception of subjectivity shifts away from the dominant psychological focus on the individual as fixed, unitary and therefore able to be quantitatively measured (Willig \& Stainton Rogers, 2008). In contrast to the humanist conception of the "unified, rational" subject, poststructuralism considers subjectivity to be "precarious, contradictory and in process, constantly being reconstituted in discourse each time we think or speak" (Weedon, 1997, p.32). Language is central to how subjectivity is shaped through its importance as a site for the construction of meaning (Gavey, 1989). When an individual is engaged in an activity such as reading, watching a film or having a conversation, they 
are being presented with possibilities of ways to 'be' in the world. As such, texts that may be considered 'trivial' are worthy of analysis, as the meaning contained within the language plays an important role. In the current research, thematic analysis followed by Foucauldian discourse analysis will be utilised to analyse the meanings of femininity constructed in the selected Snow White films. This will enable the examination of the potential subjectivities that the films make available to viewers.

\section{Analysis}

\section{Thematic Analysis}

In the first phase of analysis, a thematic analysis of the texts was conducted in order to organise the material in a meaningful, coherent way. Thematic analysis is a commonly used method of analysis within qualitative research (Braun \& Clarke, 2006). It is concerned with "identifying, analysing and reporting patterns (themes) within data" and is compatible with both structuralist and poststructuralist approaches (Braun \& Clarke, 2006, p. 79). The analysis of the texts for the current research followed the process outlined by Braun and Clarke. This initially involved familiarization with the data, which for the current project involved viewing the texts and then transcribing selected sections of the films. Scripts of the films were obtained to aid the transcription process. According to Braun and Clarke, the thematic analysis process then involves coding the data, searching for themes, reviewing themes and then defining and naming themes. This project followed a similar structure of analysis. In the second analytical phase, once the prevailing themes were identified, Foucauldian discourse analysis was used to provide a detailed textual analysis within the key themes. 


\section{Discourse Analysis}

Discourse analysis focuses on identifying discourses that are made available within a range of texts (eg media texts or interviews) through analysing the language used. The approach also looks at how these processes are implicated in broader social relations (Gavey, 1989). It is therefore a form of analysis that is "concerned with language and its role in the constitution of social and psychological life" (Willig, 2001, p. 107). The Foucauldian discourse analysis used in this project drew on Willig's (2001) outline of steps to be taken when conducting this manner of analysis. In the current project, each film underwent this analysis process, and then more overarching comparisons were developed between the texts. The first step described by Willig is the identification of discursive constructions within the texts. Firstly, a discursive object such as 'beauty' is identified. Then the researcher identifies each time there are direct or indirect references to it and notes how the discursive object is constructed. For the current project, this involved viewing each of the films and taking note of the constructions that are provided within them. The second step is to situate the constructions within broader societal discourses, which may entail discourses such as romance. Connecting these constructions to discourses will also be an important part of this project's analysis. The third stage is 'action orientation,' which involves analysis of the function of these constructions. The analysis in the current project will elaborate on the identification of discourses by focusing on what subject positions they offer and what this potentially entails for an individual's subjectivity.

The discourses made available within society provide subject positions that shape an individual's subjectivity and their world view (Willig, 2001). The fourth stage of Willig's process of discourse analysis is identifying the subject positions that the discourses provide. Subject positions are not fixed roles that are assigned to an 
individual, but "offer discursive locations from which to speak and act" (p.111). The fifth stage is 'practice,' which entails exploring how subject positions constrain or facilitate the individual's actions. The final stage is the examination of discourses in relation to subjectivity. The analysis of the current research will therefore seek to identify the subject positions and the subjectivities that are made available within the texts.

In addition to examining the discourses and the subjectivities through Willig's analysis, resistances to the dominant discourses will also be subject to analysis. Discourses are not static, but endure constant struggles and transformations (Foucault, 1978). Willig (2001) explains how it is also possible for 'counter-discourses' to develop, which can gradually transform the dominant constructions available. The analysis to be conducted will be also be concerned with examining what resistances there are to the dominant gender discourses in the texts. Approaching discourse analysis from a genealogical perspective will enable the analysis of discursive continuities and resistances across decades.

Foucauldian discourse analysis highlights the importance of taking a genealogical approach, which considers the manner in which discourses have transformed over time and how this has influenced subjectivities (Willig, 2001). Discourses are not fixed, but undergo changes according to shifts in social structures (Foucault, 1978). As Foucault (1978) explains, "we must conceive discourse as a series of discontinuous segments whose tactical function is neither uniform nor stable" (p.100). Foucault claims that it is not possible conceptualise discourses as either 'accepted or 'excluded,' but as a 'multiplicity of discursive elements that can come into play in various strategies“ (p.100). As discourses are produced within their social and historical context, it is important to consider how broader social factors are 
implicated. This can include an analysis of how institutions and social practises shape dominant modes of thinking (Foucault, 1978). Foucault's genealogical analysis of discourses of sexuality highlights the manner in which these discourses endure shifts that parallel changes in institutions such as psychiatry. The meaning associated with sex is then unable to be considered independently, as it is tied to social and historical practises. In line with Foucault's claim that discourses are intrinsically linked to history, Weedon (1997) also highlights how constructions of femininity are subject to changes across historical contexts. For example, discourses of femininity have undergone marked changes from the suffrage movement to the current postfeminist climate. In the current research, the genealogical aspect of Foucauldian discourse analysis will be particularly important to the analysis. This will enable the examination of the manner in which the gendered discourses within the texts have endured shifts and continuities.

\section{Reflexivity}

When conducting Foucauldian discourse analysis, it is not possible for the researcher to be removed from the discursive field that they are situated within (Willig, 2001). The textual analysis that is produced is also a discursive construction that is influenced by the researcher's perspective (Willig, 2001). This means that it is important to acknowledge how "our own values, experiences, interests, beliefs, political commitments, wider aims in life and social identities have shaped the research" (Willig, 2001, p.10). The following section will aim to address this important aspect of undertaking discursive analysis.

This project is influenced by my own experiences as a young woman in a social climate where postfeminist discourses of girl power continue to be regulated by traditional discourses privileging marriage and domesticity. As a consumer of media, I have noticed the way in which media revere career-focused women for their 
achievements alongside features of women's 'fairy tale weddings.' In this highly contradictory social climate, I was particularly drawn to the pervasive nature of the fairy tale narrative. I noticed that the term 'fairy tale' was continuously employed in the description of traditional, idealised romantic unions. I noticed that this was particularly prevalent in reality dating shows, with show like The Bachelor making constant associations between the fairy tale romantic narrative and the highly artificial romantic unions on the show. The prevalence of fairy tales narratives became more evident as I noticed the sheer quantity of cinematic fairy tale remakes and television shows that are centred on fairy tales. Although these tales have been transformed to appeal to modern audiences, many of their traditional elements remain persistent, such as their emphasis on being the 'fairest.'

The continuous relevance of fairy tales is also illustrated by my own continual engagement with these tales. In spite of being educated and familiar with the feminist critiques of fairy tales as deeply oppressive and inherently patriarchal (Bacchilega, 1993; Rowe, 1979), it is difficult to deny the pleasures associated with these classic tales. I recall reading the classic tales with fascination when I was a child and relishing the opportunity to dress up as a Princess. Although I am now in my early 20s, I still found myself dressing up as a fairy tale Princess for a recent costume party. Perhaps it is these pleasures associated with these classic tales that explain why they continue to hold such immense power in society despite the emergence of newer versions of femininity.

Although fairy tales are arguably ingrained in society, it is likely that the majority of women and girls are aware that fairy tales are not a realistic depiction of adult relationships. I also found that it is difficult not to view the texts undergoing analysis without a degree of cynicism, particularly the musical spectacles and dramatic 
declarations of love in the early films. It is a times frustrating to observe the earlier heroines' goodness, passivity and inability to stand up to the Queen. Indeed, after studying feminist poststructuralism and fairy tale research, my reading of these tales is likely to be more critical than when I first encountered the tales. Therefore, I am aware that my education and background will influence my interpretation of these films.

As indicated in the introduction chapter, this thesis sets out to examine the gendered discourses in Snow White films from 1916 to 2012. By utilising a genealogical approach, these texts' relationship with the socio-political climate within which they are situated can be investigated along with the continuities and divergences in representations of femininity between each of these versions identified. From this historical tracking of discourses of masculinity and femininity within the films, the subjectivities made available will also be analysed. 


\section{CHAPTER THREE}

\section{DISCOURSES OF FEMININITY IN THE EARLY FILMS}

\section{Chapter Introduction}

The following chapter will analyse the constructions of femininity in the 1916, 1937, and 1959 cinematic renditions of Snow White, examining how these constructions are positioned within prevailing discourses of femininity circulating in the film production eras. The analysis will focus on examining the continuities and divergences in the manner in which Snow White and the Queen are represented across the texts. The analysis will examine the representation of Snow as the 'good girl,' a construction that starkly juxtaposes with the 'wicked' representation of the Queen. The chapter will also investigate the moral discourse that operates in relation to these representations. Beauty is also a central element of this moral discourse, particularly the denigration of the Queen's vanity in contrast to the celebration of Snow's natural beauty. The romantic discourses mobilised in relation to this moral discourse will also be scrutinised, especially how Snow's goodness provides her with the reward of the love of a handsome, rich Prince. Of particular interest is the manner in which the texts construct romance as a form of salvation from hardship, and their glorification of 'love at first sight' and monogamy.

\section{Snow White - Goodness, Sweetness, and Suffering.}

Across the texts, Snow's goodness in spite of her suffering is highlighted, positioning her within the 'good girl' discourses described by Ussher (1997), Walkerdine (1990) and Griffin (2004). Although the age of Snow may differ across the films, she is reported to be 14 years of age in the Disney version, which indicates that the representation of Snow is particularly concerned with girlhood. According to 
Ussher, a stable of the fairy tale genre is the "beautiful but cruelly treated young woman" who "longs for rescue and salvation, yet endures hardship and misery whilst dreaming impossible dreams" (p.10). The heroine does not seek revenge upon those who mistreated her, but merely seeks to live a peaceful existence with her Prince. Ussher describes this type of character as the "masochistic heroine" who tolerates misery without voicing her concern (p.10). Walkerdine's (1990) analysis of girl's comics revealed a similar pattern to fairy tales, including the emphasis on suffering as a path to escape. She claims that hardship thus becomes "masochistic," as it "can be suffered virtuously and moved beyond" (p.92). Walkerdine found that a dominant theme in the comics was that the heroines exhibited "selfless helpfulness," where they were meekly resigned to their circumstances, yet continued helping others (p.10). Walkerdine highlights that rather than actively working towards changing her life for the better, the heroine simply continues to endure, while any displays of negative emotions such as anger are constructed as unacceptable. Across the films, Snow endures a series of hardships without any indication of dissent or anger. This absence of anger includes her servitude in the first two films (1916 and 1937) when the Evil Queen reduces her to performing servile tasks, a fate that is meekly accepted by Snow. In the 1959 version, Snow is not merely reduced to servitude, but is instead locked up in the tower by the jealous Queen. Again, Snow masks her negative emotions despite the injustices inflicted upon her.

In all three films, Snow's management of her negative emotions enables her to be positioned within traditional discourses of femininity that privilege 'sweetness' (Cancian \& Gordon, 1988) and being able to mask one's negative emotions (Walkerdine, 1990). In Walkerdine's analysis of girls' comics, she found that anger and negativity were rarely exhibited by the heroines. Furthermore, her interviews with schoolgirls found that they constructed the 'perfect girl' to be able to refrain from 
displays of anger or the creation of conflict. This indicates that idealised femininity is represented as being achieved through refraining from displaying negative emotions. Snow's management of her negative emotions is illustrated in the 1916 version, when the Huntsman confesses that he has been sent to kill her. Although she initially dismisses it as a joke, when she later realises he is serious she wraps one arm around his shoulder while clasping his hand. She exclaims “but you won’t will you? See Berthold, I don't run away - I creep into your arms!” as she throws her arms around him, continuously hugging him. He looks suitably distressed, eventually breaking away from her embrace. He then decides he is unable to murder her, kneeling down and kissing her hand. This scene underlines Snow's 'sweetness'; rather than reacting with anger and shock over potentially being killed, she merely hugs the Huntsman and sweetly persuades him to spare her. Similarly, in the 1959 version, Snow pleads with the Huntsman to spare her, causing him to drop his knife. The importance of 'sweetness' to idealised femininity during the time period of the films is highlighted in Cancian and Gordon's (1988) examination of marriage advice in women's magazines from 1900 to 1979. The authors found that in the earlier decades, "sweetness was thought to be women's predisposition, and women were supposed to have superior ability to persuade gently, through tears and love" (p.318). This echoes the representation of Snow, who 'sweetly' refrains from displaying negative emotions when faced with attempts to murder her.

In line with the other version, the construction of Snow as willing to cheerfully cope with adversities is pervasive in the 1937 version. This cheerful temperament is demonstrated in the scene where she overcomes the anguish induced by the Queen's attempt to murder her. Following the Huntsman's inability to carry out the Queen's orders to kill Snow, he abandons her in the forest. In the following scene from the film, the forest is suddenly darkened and only the glowing eyes of the forest creatures are 
visible. After rushing through the forest terrified, Snow lies in a clearing sobbing. When she looks up, the forest lightens and it becomes apparent that the menacing eyes belong to harmless forest animals. Snow apologises for frightening the animals, and then says "I'm so ashamed of the fuss I've made." Making a "fuss" is thereby constructed as undesirable behaviour for young girls. Although she has just escaped murder, she is apologising and ashamed of expressing her feelings. This is noteworthy given that traditional discourses of femininity endorse emotionality (Skeggs, 1997). However, in this scene, her emotionality is derided. The scene endorses self-monitoring of one's emotions, which is in line with Foucault's (1977) notion that individuals engage in self-surveillance of their conduct. This representation of Snow has implications via the possibilities for femininity it conveys. Through the notion that women/girls should be 'ashamed' of emotional outbursts such as crying, they are provided with the impression that they should refrain from 'making a fuss' and should carefully manage their emotions and remain cheerful.

In addition to behaving sweetly, maintaining a 'sweet' appearance is also represented as an ideal feminine characteristic. This is highlighted in the 1916 version, where Snow is preparing for a ball she knows the Prince will be attending. As she is dressed in a plain dark dress, the maids of honour offer to each lend her a piece of their clothing. After she is dressed, the maids exclaim "Oh she looks like a bride, and she's perfectly sweet. All silver and white from her head to her feet." Snow appears very pleased, smiling and raising her arms in the air. The maid's comment is interesting for a number of reasons. Looking "like a bride" is represented as a compliment, functioning to glorify matrimony. In the 1937 rendition, the importance of being "sweet" is also represented as being a female virtue. This is demonstrated in a sequence where the Dwarves are washing themselves before dinner. One of the Dwarves, Grumpy, is resisting the washing. The other Dwarves then drop him in the water, wash him, and 
then forcefully 'feminize' him by tying baby blue ribbons in his hair and beard. They all chuckle as they sarcastically remark "ain't he sweet." Calling a male sweet is depicted as an insult in this case, while in the 1916 version, Snow being "sweet" was considered a compliment.

\section{Maternal Care}

In addition to being sweet and able to cheerfully cope with adversities, Snow performs a motherly role to the Dwarves. Snow is represented as caring and nurturing across all of the early films, positioning her within traditional discourses of femininity that privilege motherhood and caring for others (Skeggs, 1997). In her analysis of working-class women's experiences of 'caring courses' Skeggs demonstrates how the performance of 'caring' characteristics functions as a means to generate more respectability. Taking up the subject position of 'caring' is achieved through displaying "unselfishness, warmth and understanding" (67). Snow is also positioned within this 'caring' discourse through her representation as a 'mother figure' to the Dwarves/ Stooges. She keeps house for them, cooks, and treats them with kindness and sympathy. In the 1937 (Disney) version, her 'motherly' role is particularly developed. On the first night of living with the Dwarves, she prepares a meal for the Dwarves. However, before she will let them eat, she inspects their hands and is shocked by how dirty they are. She then says "Goodness me, this will never do. March straight outside and wash or you'll not get a bite to eat. Although the Dwarves are reluctant, they agree as 'It'll please the Princess." This constructs Snow as the 'mother' who ensures that her 'children' are clean and washed. In Snow White and the Three Stooges, Snow also acts in a motherly fashion. The following interaction demonstrates this. As the Stooges are leaving for work, Snow follows after them with their lunches she has packed: 
Snow: And I'd be lost without you.

Stooges: I wish we were more of us. And prettier.

Snow: I wouldn't want you to be any different. I love you just as you are, all three of you.

Stooges: Gee, only our mother ever said that without laughing in our faces.

Snow: Well, I mean every word of it, now promise me you'll take good care of yourselves. I've made all the things you like best.

Her declaration of unconditional love is reminiscent of a proud mother who loves her children regardless of their appearance. The Stooges reinforce this by drawing a direct connection between her love towards them and their mother. According to Skeggs (1997), "the ideal mother intuits, takes absolute responsibility and emotionally manages all of those in her care, and others" (p.70). Snow matches this description, as she continuously shows her care towards the Dwarves, providing them with a comforting home and emotional support.

In the 1916 version of the tale, Snow White is also characterised as a 'mother figure.' While there is less emphasis on her role as a 'mother' to the Dwarves, she is still shown as taking care of the Dwarves. One scene shows the Dwarves lined up before they head off to work. Snow carefully adjusts the clothing of one of the Dwarves before they all leave. This act of paying attention to the Dwarves functions to position her within the 'caring' discourse described by Skeggs (1997). Although her 'mothering' of the Dwarves is less developed than in the later versions, the characterisation of her as a 'caring' individual is further emphasised by the scene where she is taking care of the Huntsman's three children. At the beginning of the film, Snow arrives at the Huntsman's cottage to fetch ducks for the Queen. When she arrives at the cottage, the children run up to her and embrace her. When the Prince first meets Snow, she is accompanied by the children. As she introduces herself to him, she has her arms around the two girls. Afterwards, when the Prince and Snow are talking in front of the fireplace, the children climb up onto Snow's lap. Snow's connection with the children 
functions to present her as a 'caring,' 'motherly' woman who is able to look after children. This maternal representation of Snow is in line with the conception of the 'Madonna,' an idealised version of femininity that centres on the image of a woman with her child.

\section{Snow as the Cheerful Housekeeper - Domesticity and Servitude}

In addition to being characterised as maternal and emotionally supportive of the Dwarves/Stooges, Snow also happily performs domestic work. The portrayal of Snow as a servant in the two earliest films highlights the distinction between how domestic work performed in the context of servitude differs from voluntary work. In the 1916 version of the film, Snow White's role as a domestic servant is stressed in a scene at the beginning of the film. The maids of honour are gathered in the palace, gossiping about the Evil Queen's (Brangomar) treatment of Snow. A maid recounts to the other maids how the Queen has "made her sweep and dust the palace, and now Snow White is almost like a kitchen maid.“ This suggests that Snow’s performance of domestic work is involuntary and consistent with that of a servant, despite being born into royalty. However, it is noteworthy that she is "almost a kitchen maid," demonstrating that her royal breeding prevents her from being entirely perceived as a servant. After this scene, the film cuts to the palace kitchen where Snow is shown emerging from a large pot that she has crawled into in order to scrub. She is wearing a plain dark dress, although the dress has no holes in it and she appears tidy. The Queen then strolls into the kitchen; and while standing at the entrance of the kitchen exclaims "take care, Cook, that she does not lie idle." In contrast to Snow toiling away on the ground, the Queen is positioned at the top of the steps leading to the kitchen, enabling her power over Snow to appear enhanced. This scene suggests that by reducing Snow to the level of a servant, 
the Queen has asserted her power and superior social standing. Furthermore, domestic labour in the context of servitude is represented as monotonous and demeaning.

In the 1937 version, Snow is also performing tasks consistent with servitude. In the prologue, it is stated that "her vain and wicked stepmother the Queen feared that some day Snow White's beauty would surpass her own. So she dressed the little Princess in rags and forced her to work as a scullery maid." In the opening scene of the film, Snow is shown scrubbing the steps of the castle clad in a ragged dress. She appears cheerful, humming while she works. The only indication that the task may not be enjoyable for her is when she sighs wistfully. Consistent with the cleaning scene in the 1916 version, this scene may also be read as constructing Snow's engagement in domestic labour as a means for the Queen to reduce her social standing and humiliate her. When considering Snow's role as a domestic servant, it is important to further examine the role of class in these representations. Skeggs (1997) explains how domestic servants were a key aspect of maintaining the ideal domestic environment. However, she also contends that these domestic servants were vilified, dehumanized and perceived as promiscuous and devoid of morals.

While Snow is performing tasks consistent with servitude, she does not conform to this characterisation of a servant. In the 1916 and 1937 version, Snow's occupation as a servant clashes with her otherwise virtuous and pure persona. In both of the films, the Prince is her first kiss and in the 1937 version, Snow is even shown praying. This demonstrates that regardless of the menial tasks she is forced to endure, her 'true class' shines through. According to Foucault (1978), the "technologies of sex" serve as a manner of surveillance over what constitutes appropriate sexual behaviour. Drawing on Foucault, Smart (1983) explains how the ruling classes were initially the subjects of surveillance over what constitutes appropriate bodily and sexual behaviour. In contrast 
to the bourgeoisie, the working classes were not concerned with their body or sexuality. In this sense, being 'high class' was inextricably linked with virtue (Smart, 1983). Similarly, in the Snow White films, class is connected to her virtuous representation. In contrast to the earlier films, Snow White is not a servant in the 1959 version. This would be consistent with changes in the structure of the labour market, where having white, domestic servants was becoming less prevalent in America (Duffy, 2007). However, in 1916 being a domestic servant remained a common occupation for women (Duffy, 2007).

While both of the early films represent servitude as a form of punishment, Snow's completion of voluntary domestic labour in all of the three films is depicted as central to her presence being desired by the Dwarves/Stooges. Traditional discourses of femininity are concerned with women being domestically competent (Jackson \& Tinkler, 2007). Highlighting the domesticity of traditional femininity, Jorgensen's (2013) feminist analysis of Snow White, describes the tale as "but one outlet of Western society insisting on the importance and imbrication of traits that are supposedly inherently feminine" including an "affinity for the domestic sphere" (p.128). Consistent with Jorgensen's analysis, the character of Snow White across the early films is positioned within traditional discourses of femininity, in part through the construction of her as a 'housewife' who cheerfully cleans and prepares meals for the Dwarves (or the Stooges in the 1959 version). In these films, it is evident that the Dwarves/ Stooges wish for Snow to remain in their homes due to her ability to 'keep house' for them.

The 1916 version represents Snow's performance of domestic labour in the Dwarves' cottage as a means through which she gains their acceptance. When she arrives at the cottage, she eats a few scraps of food from the Dwarves' plates. After she has eaten, she exclaims that "I'd like to do something to pay for my supper," before she 
starts sweeping. She does not look particularly pleased to be sweeping, approaching the work as a chore. This scene illustrates that she is aware that her domestic labour is able to pay for her presence in the house. However, her domestic qualities are not developed beyond this initial volunteering to clean the house. On one hand, this cinematic version of the tale was situated in the early $20^{\text {th }}$ century, when the primary subject position for a woman to take up would be that of the housewife or the domestic servant, as these were the most common occupations available during that time period (Duffy, 2007). On the other hand, however, the film was also produced in a time period where the suffrage movement was making significant advances, gradually securing the vote for women (Walby, 1997). This may be related to why the construction of housework as labour is highlighted, and the construction of Snow as the 'housewife' is less glorified than in later versions.

In the 1937 rendition of Snow White, the domestic element of Snow's character is developed extensively. When Snow arrives at the Dwarves' cottage, she is shocked by the untidy state of their house. There are piles of dishes on the table, clothes on the floor and cobwebs clinging to most items. As she inspects their home, she gasps and appears horrified at the state of the house:

Snow: Why, there's seven little chairs. Must be seven little children. And from the look of this table, seven untidy little children.

A pickax. A stocking too [laughs] and a shoe [astonished whistle].

And just look at that fireplace. It's covered with dust. And look, cobwebs everywhere. My, my, my! What a pile of dirty dishes [gasping] and just look at that broom [the broom is covered in cobwebs]. Tsk, tsk, tsk tsk, tsk, tsk!

Why, they've never swept this room. You'd think their mother would-- [gasping] maybe they have no mother. Then, they're orphans. That's too bad [looks sad].

I know. We'll clean the house and surprise them! Then, maybe they'll let me stay!

This scene is noteworthy for a number of reasons. Firstly, like the 1916 version, it also connects cleaning the house with being able to remain in the Dwarves' home. 
Cleaning is thereby constructed as a means to be of value to the Dwarves, a form of labour that can be exchanged for shelter. Although she is shocked as she inspects the house, she cheers up when she comes up with the idea of cleaning the house. She realises that she can be of value to the Dwarves if she transforms their house for them. It is also interesting that the untidy state of their house is connected with their perceived lack of a mother. In this sense motherhood is associated with maintaining a tidy home. Snow thus becomes their 'substitute mother' who can take care of them and their home. This positions Snow within traditional discourses of femininity that privilege motherhood and domesticity (Skeggs, 1997).

The representation of Snow as embodying traditional feminine characteristics is further enhanced in a cleaning scene. Her housework is accompanied by the song Whistle While You Work:

Now, you wash the dishes

You tidy up the room

You clean the fireplace

And I'll use the broom

[Singing begins]

Just whistle while you work

[Whistling]

And cheerfully together

We can tidy up the place

So hum a merry tune

[Humming]

It won't take long

When there's a song

To help you set the pace

And as you sweep the room

Imagine that the broom

Is someone that you love 
And soon you'll find

You're dancing to the tune

[Spoken]

Oh, no, no, no, no!

Put them in the tub

[Singing continues]

When hearts are high

The time will fly

So whistle while you work

This musical interlude serves to construct Snow as a domestically competent girl who approaches housework with enthusiasm and excitement by distracting herself with songs and romantic fantasies. Rather than depicting housework as a monotonous chore, this song portrays it as a fun spectacle. This construction of housework as pleasurable is in stark contrast to the earlier grim representation of housework within the context of servitude. Unlike the earlier scene showing her toiling alone and cleaning the castle steps, this scene shows her delegating various tasks to the animals, making the cleaning a group effort that they can complete "cheerfully together." By the end of the song, Snow and her helpers have swept, done the dishes, tidied the house, done the laundry and even arranged fresh flowers on the table. Through this hurried transformation, housework is represented as easy and pleasurable.

This representation of housework as 'fun' takes on an illuminating analysis with Skeggs' (1997) use of the Foucauldian notion of reproductive power to explain how working class women in the early 20th century were compelled by the middle-class to view domesticity as pleasurable. This form of 'power' functions by persuading those of lower classes that the menial labour they are performing is indeed pleasurable, effectively making them more likely to continue performing those jobs. According to Skeggs, "if pleasure can be gained from that which is oppressive it is far easier not to 
notice the oppressive features of it" (p.45). In this sense, there is no direct control needed to persuade people to perform these jobs, as they are willingly engaging in them. Skeggs highlights how many of the courses offering domestic training to British women in in the early $20^{\text {th }}$ century functioned to prevent them from working in factories. Instead, they were encouraged to find enjoyment in performing domestic labour. The director of Snow White (1937) appropriates this idea in this construction of housework as enjoyable and rewarding.

The benefits associated with being domestically competent are further enhanced by connecting housework with romantic fantasies and pleasure. In the 1937 version, the connection between romance and domesticity is highlighted when Snow instructs the audience to "imagine that the broom is someone that you love and soon you'll find you're dancing to the tune." This serves to indicate that the cleaning is not something done for her personal fulfilment, but rather is made enjoyable through fantasising about a romantic prospect. Snow does eventually marry her Prince, which may suggest that romantic fantasies can be rewarded if one works tirelessly and happily. The link between romance and domestic pursuits is further enhanced when Snow is later depicted baking a pie, while singing about her dreams that "some day my Prince will come." The film thereby functions to represent being competent at housework and cooking as enjoyable through the benefits that can be derived from it: through enthusiastically 'keeping house,' she is provided with a home and also domesticity is rendered desirable through romantic fantasies.

The classic fairy tales such as Snow White are a primary example of texts that rely on fantasy and desire. The 1937 version of Snow White constructs escape from a life of drudgery as available through romantic fantasy. Walkerdine (1990) claims that fantasy and desire are central aspects of the appeal fairy tales present to their audience. 
She claims that fantasy is particularly enticing for a reader because it requires active participation with the text and a vicarious sense of gratification when the characters achieve their goals. While there is little relationship between fairy tales and everyday life, the tales construct a potent image of an imaginary future devoid of hardship and escape from their current economic situation. Snow White is a classic 'rags to riches' story that adheres to this notion of 'fantasy.' Snow is initially an orphaned, persecuted servant, but by the end of the tale she is swept off her feet by a handsome Prince. While this is a very unlikely scenario for any girl to experience, the tale is likely to be consistent with many working-class girls' dreams of escaping their poverty through marriage. Indeed, the 1937 version of Snow White's connection between romantic fantasy and domesticity is consistent with Walkerdine's description of what 'fantasy' entails.

Snow's domestic skills also extend to cooking, which is illustrated in a scene in the 1937 version where the Dwarves return home and Snow pleads with them to let her stay in exchange for keeping house for them :

Snow White: Oh, she'll [the Queen] never find me here. And if you let me stay, I'll keep house for you. I'll wash and sew and sweep and cook and--

All Dwarves: [in unison] Cook?

Doc: Can ya make dapple lumpkins-- uh, lumple dapplins-- apple dumplings!

Grumpy and Sneezy: Apple dumplings!

Doc: ah, yes! Crapple dumpkins.

Snow White: Yes, and plum pudding and gooseberry pie--

All Dwarves: Gooseberry pie? Hurray! She stays! [sniffing].

Grumpy: Ah! Soup!

All Dwarves: Hurray!

This scene suggests that the promise of her cooking skills is so enticing that the Dwarves are willing to face the danger of harbouring her. While her willingness to 
'keep house' and clean produces little reaction, cooking is represented as the ultimate asset to the household. Hollows' (2007) feminist analysis of domestic femininity highlights how cooking is a key aspect of how the stereotypical housewife is constructed. Hollows explains how cooking can serve as a primary means for women to show their affection and ability to care for others. As 'caring' is perceived as key to the construction of women's subjectivities, the association between cooking and caring renders cooking a traditionally feminine pursuit (Hollows, 2007). Skegg's (1997) research on women enrolled in 'caring courses' also demonstrates how being 'caring' can serve as the ultimate form of 'feminine cultural capital.' Furthermore, for the working-class women she interviewed, taking up the subject position of 'caring' allowed them to generate the respectability women of their class were socially perceived to lack. Through her cooking, Snow becomes 'caring' and useful and is consequently afforded a position as a desirable member of the household. Although the image of the woman cooking a meal for others is revered, it has also been criticised. According to Giles (2007), cooking has served as a means for feminists to dissociate themselves from women that they believed were confined within the domestic sphere. Cooking thereby became one of the means through which women's oppression was represented. In the 1937 version of Snow White, cooking is particularly glorified. This is ironic in light of the film being produced within the Great Depression, a time period where resources were limited. Due to the scarcity of food, it is likely that films at the time were particularly concerned with projecting the fantasy of the cheerful 'housewife' concocting up an array of dishes. The films may thereby serve as a form of fantasy and escape from the current circumstances.

Although domesticity is not as glorified as it is in the 1937 version, it is still prevalent in the 1959 version. When Snow, Quatro (the Prince) and the Stooges arrive at the Dwarves' cottage, they divide the tasks involved in making breakfast. The 
Stooges offer to get eggs, set the table and start the fire. The Prince volunteers to find firewood and Snow suggests making bread. Snow's offer of making bread positions her within traditional discourses of femininity. Although it is notable that she is not preparing the meal by herself but is aided by the men, the traditional division of labour persists. Finding firewood and starting a fire are more consistent with traditional male tasks, while setting the table and fetching eggs are more traditionally within the realm of feminine tasks. As mentioned earlier, cooking can provide a means for women take up the subject position of 'caring' (Giles, 2007). Skeggs (1997) explains how the consequence of taking up this caring position is that it ultimately reinforces the sexual division of labour, as is demonstrated by this scene. Snow's role as a cook is further highlighted when she reminds the Stooges to remember the lunch she has packed them, saying "I've made all the things you like best." The connection between femininity and domesticity is further enhanced in a scene where Snow remarks that "those floors, I don't think they've been scrubbed for years," and Quatro responds “that's because the seven Dwarves are bachelors." This serves to construct men as incapable of cleaning, constructing it as a 'woman's job' and reinforcing the gender polarity of the labour divide.

\section{Romance - The Reward for Being a 'Good Girl'}

The ultimate reward for Snow's sweetness, kindness and tireless domestic drudgery is the love of the handsome and rich Prince. Wilkinson and Kitzinger (1995) define romance as a "text which presents an image of redemption, of salvation and rescue. Usually, but not necessarily, this is presented as a heterosexual passion" (p.132). Ussher (1997) highlights how the narrative of "some day my prince will come" is central to fairy tales. McRobbie's (1991) analysis of romance in Jackie magazine further highlights the importance placed on romance in media targeted at girls. In the magazine, 
romance is represented as the primary concern for girls. Her analysis found that the stories within the magazine depicted romance as "important, serious and relevant" yet simultaneously "fun," the "essence to life" and the "key to happiness" (p.80). Similarly, in fairy tales, romance provides the means to escape hardships and turmoil and achieve the 'happily ever after' (Ussher, 1997). Romance is the fairy tale heroine's primary concern in life, surpassing all other goals. As in Walkerdine's (1990) analysis of girls' comics where a man serves as the ultimate salvation from a life of drudgery, a narrative of rescue through men is particularly salient in the early Snow White films.

Across the early three films, Snow is depicted as a 'damsel in distress,' whose salvation from a life of hardship is dependent on men. As already noted, Snow is effectively homeless before she gains shelter from the Dwarves/Stooges and in return for her domestic skills she is provided with a home. While the Dwarves provide temporary help, it is the Prince that ultimately saves her. In the 1916 version, however, Snow is not directly saved by the Prince. After being put in a coma by the poisoned apple, her 'death' is mourned. Snow is depicted lying in an open coffin, surrounded by flowers and bathed in white light. The men then transport her to the castle to make the Queen account for her murderous actions. However, the piece of poisoned apple has dislodged from her throat on the journey, and she wakes up. That Snow is not actually saved by the Prince but by is awoken by chance, which may function to diminish his role as saviour. In contrast with the 1916 version, in the Disney (1937) version it is the kiss of the Prince that awakens her. She is helpless and confined to an eternal coma until the Prince saves her with his kiss. As in the 1916 version, Snow is lying in an open coffin when the Prince approaches her. Kneeling down, he gently plants a kiss on her mouth. Immediately after she awakens, he lifts her up on his horse, leading her away with him to his castle visible in the clouds. 
In Snow White and the Three Stooges (1959), she is not awakened by the kiss of the Prince, although his declaration of love is represented as what prompts her awakening. In the following scene, the Stooges and the Prince are mourning Snow's apparent death.

Stooge: She was so beautiful, we didn't have the heart to bury her.

Prince: [Kneels down] Oh my beloved! If you leave me I have nothing more to live for. Tell me you're asleep. Wake my love, please wake. Come back to me Snow White. Come back, I beg you. Please come back [he hugs her close and she awakens].

Stooges: Snow White's alive, it's a miracle!

Prince: My love, my love. I knew I hadn’t lost you. I knew it, I knew it.

In this scene, the Prince's love is constructed as her salvation. When she hears his declaration of love, the spell is broken. Love serves as the ultimate salvation from hardship, and is powerful enough to break the Queen's evil spell. In all of the films, love is represented as an omnipotent force with magic transformative powers. This echoes a broader societal infatuation with love. As Lindholm (1998) explains, media originating from America often depicts love as "life's ultimate value: overwhelming, ecstatic and uniquely blissful. Love our clichés tell us, makes the world go around, nothing is impossible for lovers, love knows no boundaries, life without love is not worth living, and love is forever" (p.18). Despite the Queen's cruel attempts to separate Snow from the Prince, their love prevails and they live "happily ever after." The classic fairy tales such as Snow White are a primary example of texts that rely on the fantasy and desire as described by Walkerdine (1990). Across the Snow White films, romance is central to this fantasy, serving as the prize for her patient suffering and constructing a fantasy of 'love conquering all.'

Across the data set, the classic romantic narrative is a central aspect of the tales. Romance is a pervasive narrative, and is particularly targeted at women (Wilkinson \& Kitzinger, 1995). According to Wilkinson and Kitzinger, it is a narrative that "women 
are supposed to want and men to reject. Women are supposed to do the romance in a relationship, and men are supposed to do the sex. In popular culture, women and girls are assigned romantic fiction and men and boys pornography" (p.133). Stacey and Pearce (1995) chronicle how the traditional romantic narrative traditionally starts with the characters meeting and displaying mutual attraction, then the plot moves to them overcoming barriers and obstacles. At the end, 'love conquers all,' functioning to illustrate the vast power of love. This has notable parallels with the manner in which romance is represented across the early Snow White films (1916, 1937, and 1959). The relationship unfolds in a similar fashion in all of the films. The Prince meets Snow and, struck by her beauty, he immediately falls in love with her and proposes marriage. However, the Queen's jealousy drives them apart and they are forced to separate. Snow continues to pine for her Prince, and her waiting is eventually rewarded with marriage. There are no conflicts between Snow and her Prince, the only barrier to their relationship being the Evil Queen's jealous antics. According to Cancian and Gordon (1988) the marriage advice in earlier decades dictated that "after the right preparations and choices had been made, marital love would thrive spontaneously with minimal caretaking." This echoes the representation of love in the films, where love is represented as 'easy' and effortless. Moreover, once the couple lives 'happily ever after,' there is no concern with what the future holds for their relationship. This supports Kitzinger and Wilkinson's (1995) claim that romantic narratives are not concerned with everyday life or long-term developments in the relationship, thus providing a very temporary representation of the process of 'falling in love.' In her analysis of romance in the magazine's picture stories, McRobbie (1991) found that there was a concern with the grand romantic gestures such as the proposal, rather than the long term progression of the relationship. In the 1937 version the glorification of the grand romantic moments is particularly salient. At the beginning of the 1937 film, Snow 
is shown cleaning the steps of the castle. She then makes her way over to the wishing well and begins singing about her yearning for a prince to appear.

Snow: I'm wishing for the one I love to find me today

I'm hoping and I'm dreaming of the nice things he'll say

The Prince immediately appears, although Snow is startled and runs to a balcony. As he starts singing, she emerges from the balcony and listens to his serenade:

Prince: Now that I've found you hear what I have to say

One song I have but one song

One song only for you

One heart tenderly beating

Ever entreating

Constant and true

One love that has possessed me

One love thrilling me through

One song my heart keeps singing

Of one love only for you

Despite having only just met her, the Prince is immediately smitten with her, mobilising the 'love at first sight' narrative, where love is represented as 'easy' and immediate. By the end of the song, Snow's yearning for her Prince has been rewarded, as he sings of "one love only for you." Monogamy is thereby proposed by the time their duet has been completed, despite the characters not having previously interacted. The glorification of 'love at first sight' is not confined to fairy tales, as it is ingrained in broader societal expectations of what idealised romance encompasses. Media targeted at women often contain a vast emphasis on romance, which in turn can have important consequences for women's subjectivities (Stacey \& Pearce, 1995). Previous research has found that women tend to identify with the 'love at first sight' narrative when they are describing the manner in which they met their partner (Davidson, 2007; Langford, 
1999; Leonard, 1982). Davidson remarks how this emphasis on 'fate' and 'love at first sight' is complicated by the reality of finding love. She points out how this can produce anguish and anxiety in women, as they feel under pressure to meet prospective partners in a fashion that adheres to this.

In Snow White and the Three Stooges (1959), there is also a quick progression to romance. However, there is less emphasis on the 'love at first sight' narrative in comparison to the Disney version. Snow meets Quatro (the Prince) through the Stooges. After living at the Stooges' house with Snow, the Prince begins to develop feelings for Snow. His initial display of interest takes place in the form of a puppet show. The puppet sings:

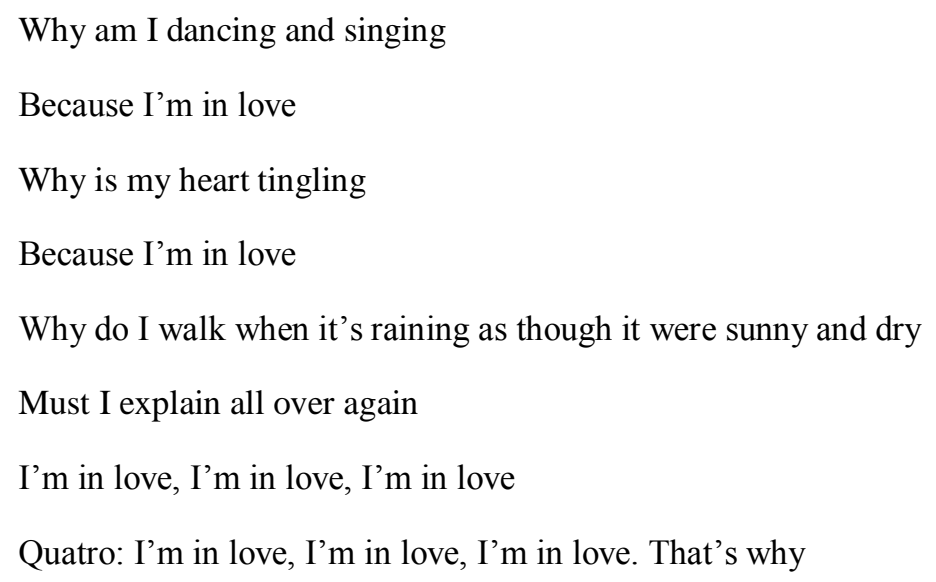

Quatro is holding the puppet (Quinto), serenading Snow. In this song, love is represented as an overpowering, intense emotion. It is a source of powerful happiness, causing the recipient to "dance," "sing" and feel as though rain is sunshine. This produces an impression that love is of a blinding nature, distorting one's sense of one's environment. While Snow is being serenaded, the Prince is on his knees performing the puppet show, staring earnestly into her eyes. This is reminiscent of Wetherell's (1995) description of the subject positions that romantic discourses provide. According to Wetherell, the classical romantic narratives have been critiqued for positioning women 
as passive while the men are active. It is generally the men that initiate the courtship and are endowed with the power to decide what is recognised as a romance. However, women also hold considerable power within romantic discourse. While romance can be perceived as rendering women marginalised and powerless, it can simultaneously be a means to gain power over men and can thus be a source of pleasure. As Wetherell describes it, this may be "because it reveals the man squirming uncomfortably on the hook of his love for the heroine. His feet cut from under him, he grovels on bended knee" (p.142). This contradiction of romance is mirrored in the manner in which romance in the aforementioned sequence is presented. When the Prince declares his love, he is literally on his knees while she sits in a chair and observes his serenade. This may be read as her being endowed with the powerful position of being able to accept or reject his advances.

In Snow White (1916), the characters also rapidly fall in love, although like the 1959 version, the progression of their relationship is slightly slower and less dramatic than in the Disney (1937) version. In the 1916 version, the Prince first encounters Snow when he is out hunting. Snow has just released some birds from captivity, when the Prince encounters the birds and attempts to shoot them. Accompanied by the Huntsman's children, Snow runs towards him, throwing her arms around him and begging him to spare the birds. They introduce themselves, and the Prince and Snow returns to the Huntsman's cottage with the children where they spend time conversing in front of the fire place. Clearly smitten with her, he asks "shall we see each other again, fair one?" to which she replies "perhaps." The decision to represent Snow as reluctant to immediately display interest aligns her with the notion of 'playing hard to get.' Traditional scripts of courtship dictate that the men are responsible for the 'chasing,' while the women are expected to passively wait (Langford, 1999). Ussher 
(1997) highlights how 'playing hard to get' is in itself contradictory. While being attractive and unattainable is prized, so is being in a relationship.

\section{Beauty and the Queen}

In fairy tales, the heroine's appearance is a key factor in her ability to receive the ultimate reward of the Prince (Ussher, 1997). Across the films, beauty is represented as the ultimate source of power. In society, beauty is glorified and "we enter and know our positioning in relation to others via their bodily and visual value" (Skeggs, 2001, p.303). Previous analysis of media targeted at women has highlighted the emphasis that is often placed on beauty (McRobbie, 1991; Ussher, 1997). Beauty is also often related to desirable personality traits such as goodness, kindness and high morals (Black \& Sharma, 2001). This is evident in the characterisation of Snow White, whose beauty is accompanied by a self-less, kind attitude. In contrast, when the Queen transforms into an 'old hag,' she deceives Snow into eating the poisoned apple. In this sense, the film constructs being an 'old hag' with not being trustworthy. This serves to connect beauty with goodness, and lack thereof with 'wickedness.' According to McRobbie's (1991) analysis of Jackie, being deemed attractive is central to femininity and is represented as "the girls' passport to happiness and success," a sentiment echoed in the Snow White films (p.104).

In addition to the focus on beauty, films privilege Snow's 'natural' and effortless beauty over the Queens' obsession with her appearance. This mobilises a moral discourse that pathologises vanity and celebrates natural beauty. The glorification of natural beauty is illustrated in the opening scene of the 1937 version, when the Queen consults the magic mirror to find out whether she remains the fairest.

Queen: Magic mirror on the wall, who is the fairest one of all?

Mirror: Famed is thy beauty, majesty. But hold a lovely maid I see. Rags cannot hide her gentle grace. 
Alas, she is more fair than thee.

Queen: Alas for her! Reveal her name.

Mirror: Lips red as the rose. Hair black as ebony. Skin white as snow.

Queen: Snow White!

In this scene, the Queen is instructed that while she remains beautiful, Snow has outshone her. It is noteworthy how the dialogue states that "rags cannot hide her [Snow's] gentle grace" because it serves to represent Snow's beauty as a more authentic form of beauty that can shine through despite her being clad in rags. The mirror's construction of Snow as having "gentle grace" seems to be appropriating an idealised, traditional form of feminine beauty that is soft, graceful and natural. McRobbie's (1991) analysis of Jackie highlights that while beauty routines were deemed essential, there was simultaneously an undercurrent of embarrassment that beauty is not "natural" but requires so much work to be maintained. In this sense, although being attractive is the ultimate goal, the journey to achieve it is fraught with embarrassment. Similarly, vanity is recognised as part of womanhood, although it is also heavily criticised (McRobbie, 1991). Mitchell (1940, as cited in McRobbie, 1991) supports this with the following quote: "She has to develop her threatened narcissism in order to make herself loved and adored. Vanity, thy name is woman“ (p.108). The condemnation of vanity in a sense operates within a moral discourse where vanity is punished. For women and girls, being positioned within this moral discourse can have an impact on the way in which their subjectivity is shaped. For example, research has shown that women constructed the 'natural look' as the ultimate goal of their beauty practises, while vanity was denigrated (Black \& Sharma, 2001; Clarke \& Griffin, 2007).

In contrast to the positive representation of Snow's natural beauty, the Queen is vilified for being vain and is ultimately punished for it. In the 1916 version of the tale, the Queen enlists the help of a witch to improve her appearance. The Queen's 
appearance is initially not aligned with normative standards of feminine beauty.

However, as she drinks the potion, her former large, hooked nose is changed to a small, neat nose and her short, straggly hair is converted to long, thick braids that hang below her waist. Her clothing is switched from a high necked dress with minimal embellishments to a more low-cut bedazzled dress. She is also suddenly wearing jewellery and is no longer wearing a hat. As the Queen feels the potion beginning to work, she appears astonished, bringing her hands to her face and her new hair while smiling. As she looks in the magic mirror, she continues beaming. Through the Queen's gleeful expression, beauty is constructed as vastly significant and empowering. However, the witch informs the Queen that "this mirror will always answer you truthfully. If you ever break the mirror you will become as ugly as you really are." This highlights that the Queen's beauty is inauthentic and temporary. At the end of the film, the Queen breaks the mirror, revoking the spell and returning the Queen's appearance to its former state. In the moment of loss, she appears distraught, throwing herself to the ground in front of Snow White and fleeing the room. The moment coincides with Snow being crowned the new Queen, further highlighting the negative implications of the Queen's vanity. Through her vanity, the Queen loses both her temporary beauty and her power.

This moral tale is further reified in the Disney (1937) version. In a reversal of the unattractive to beautiful transformation, the Queen consumes a potion that disguises her as an 'old hag' in order to carry out her plan to kill Snow. After the attempted murder, the Dwarves chase after the Queen. As she flees to a cliff top she is struck by lightning. She is still in her 'hag' state as she falls to her death. While her death is in itself a severe punishment, it is enhanced by the fact that she is forced to die a 'hag.' It may also suggest that she is truly a 'hag,' despite the earlier description of her as possessing a beauty only rivalled by Snow. The scene suggests that the Queen's vanity 
is what eventually leads to her death. If she had not attempted to murder Snow, then she would not have met this unfortunate fate.

Through this moral discourse, Snow's beauty is rewarded while the Queen is ultimately punished by death or complete loss of powers. The tales depict vanity as a great moral transgression, which serves to demonstrate the contradictions inherent in the way in which the tales represent beauty. Skeggs (2001) found that while the women she interviewed considered beauty an asset, displays of vanity were often disparaged. The women in her research described how the act of publicly applying makeup in contexts such as a toilet in a nightclub can function as a way to assert one's value in the presence of other women. Applying makeup in public makes it explicit that one is seeking to invest in one's appearance and receive the reward of male attention. However, being publicly invested in one's appearance was simultaneously scorned by the other women and deemed excessively vain. In this sense these 'vain' women were perceived as "both sad and dominating" (Skeggs, 2001, p.302). The manner in which the renditions of Snow White represent the Queen's vanity adheres to this perspective. While the Queen's powers stem from her beauty, her obsession with her appearance also renders her desperate and pitiful. Similarly, Radway (1981) found that the female villains in Gothic Romance novels were defined by their vanity and self-obsession. This was in stark contrast to the heroines, who cared about others and were rarely concerned with capitalising on their appearance. While the heroines were perceived by others as beautiful, they generally had a modest opinion on their own looks. The heroines were rewarded with romantic fulfilment for their modest beauty, while the villain never received this valuable reward. This upholds the construction of natural, unassuming beauty as prized and vanity as fruitless, similar constructions echoed throughout the renditions of Snow White. 
The Queen's jealousy of Snow's natural beauty is articulated in the Queen's fierce competition with Snow. Throughout media such as fairy tales and magazines, women are presented as essential sources of friendship, fun and support (Ussher, 1997). However, they are simultaneously depicted as posing a significant threat, particularly concerning the ability to attract and maintain the affections of a man (McRobbie, 1991; Ussher, 1997). Consequently, other women are not trustworthy unless their appearance is grotesque (McRobbie, 1991). This produces a competitive, jealous environment where camaraderie is secondary to keeping one's man. Female competition is particularly salient in Snow White where female characters epitomise this competition between females.

The Queen's fierce competitiveness towards Snow is particularly salient in the 1937 version of the tale. Snow's beauty and youth as a threat to the Queen and the jealousy stemming from it are made explicit in prologue:

\footnotetext{
Once upon a time lived a lovely little Princess called Snow White. Her vain and wicked stepmother the Queen feared that some day Snow White's beauty would surpass her own. So she dressed the little Princess in rags and forced her to work as a scullery maid.

Each day the vain Queen consulted her magic mirror, "magic mirror on the wall, who is the fairest one of all?" ... and as long as the mirror answered "You are the fairest one of all," Snow White was safe from the Queen's cruel jealousy.
}

Thus, from the very beginning of the film, the tale is constructed as one centrally concerned with jealousy between women. After the mirror reveals that Snow is has surpassed her looks, the Queen looks down from her window and sees Snow being serenaded by the Prince, as described earlier. She widens her eyes with disgust, dramatically shutting the curtains. She then instructs the Huntsman to kill Snow and bring back her heart. Later, when he realises he is unable to kill Snow, he exclaims "She's mad! Jealous of you! She'll stop at nothing! This reinforces the construction of the older woman, gripped with an irrational fear of not being the 'fairest.' This serves to 
construct women as competitive and jealous of one another. Lemish and Muhlbauer (2012) claim that the "hegemonic discourse that reinforces women's rivalry undermines the possibility of women's bonding, sisterhood, and friendship that allow the collective building of social and political power" (p. 171). They consider that the representation of women as competitors in texts such as Snow White ultimately functions to lessen women's political power. The authors suggest that rather than uniting to change current social conditions, women are distracted with competing with one another. Instead of being respected sources of expertise, experience and support for younger women, older women are instead constructed as threatened by youth. In particular, it is the older woman who cannot bear the thought of losing her looks and by extension her power. Across the films, Snow's beauty is represented as the main source of the Queen's jealousy. Ussher remarks that the plot of fairy tales is reminiscent of a beauty contest, where only the fairest is rewarded. This competitive environment creates a rift between women, leading to conflict and jealousy. Ussher (1997) describes this as a "celebration of envy and competitiveness between women which perpetuates the suspicion that those who are ugly and old are in fact 'wicked"' (p.11). This has consequences for girl's subjectivities, as they may feel increased pressure to strive for unrealistic beauty goals. Furthermore, rather than viewing other women as support, they are encouraged to view women as competitors.

\section{The Queen and Maternalism}

Not only is the Queen negatively constructed as vain, but also, unlike Snow, as devoid of any maternal instincts. Traditional discourses of femininity consider motherhood to be a key element of being a woman (Gillespie, 2000; Radtke \& Jacques, 2012). The Queen's lack of maternalism prevents her from being positioned within these maternal discourses. Across various popular culture texts, villainous women are 
often defined by their opposition to motherhood. Aguiar (2001) argues, for example, how infamous characters in literature, such as Lady Macbeth, are defined by their disavowal of motherhood. The character of Alex in Fatal Attraction (1987) is another 'evil' character who is defined by her opposition to motherhood, in contrast to Beth, wife of the man she has an affair with (Bromley \& Hewitt, 1992). Unlike Alex, Beth is a nurturing stay-at-home mother whose maternalism allows her to be positioned within the caring discourses described by Skeggs (1997). This clash between the 'good' maternal woman and the 'bad' childless woman echoes in the plot of Snow White, where the evil Queen's childlessness is juxtaposed with Snow White's maternal instincts towards the Dwarves and the Huntsman's children, as described earlier.

\section{The Queen and Witchcraft}

Across all of the films, the Queen is aligned with witchcraft. In the 1916 version of the film, she enlists the help of a witch to transform her appearance. However, in the 1937 and 1959 version, she performs her own witchcraft. This may function to intensify the representation of the evil Queen's relationship with witchcraft. Lemish and Muhlbauer (2012) claim that media representations of older women often adhere to a "bitch-witch" stereotype, originating from the early historical fears of women being aligned with witchcraft. For example, in literature, archetypical 'evil' characters such as Lady Macbeth are also involved in witchcraft (Shakespeare \& Braunmuller, 2008). Lemish and Muhlbauer describe how throughout history, the "witch-bitch" is believed to be capable of destroying her enemies through black magic. As described earlier, she is a woman gripped by vanity and is fiercely jealous of younger women who may possess superior beauty. She is also selfish, acting independently to achieve her goals and caring little about who she harms in the process. Historically, women who dared resist dominant discourses of appropriate gendered behaviour were often deemed a 
witch (Aguiar, 2001). Branding a woman a witch often served as a means to rob a powerful woman of her power. However, Purkiss' (1996) examination of the witch in historical context claims that being deemed a witch also often arose from females feeling threatened by another woman. This counters the perception that it was only men that targeted women as being witches, as it was often women that accused one another.

This "witch-bitch" representation applies particularly well to the Queen in Snow White. In the 1937 version, the Queen's characterisation as a witch is particularly developed. In the following scene, Snow has just arrived at the Dwarves' cottage and is pleading with them to let her stay after they discover her asleep in their house.

Snow White: Please, don't send me away. If you do, she'll kill me.

All dwarfs: Kill you?

Various dwarfs: Who will? Yes, who?

Snow White: My stepmother, the Queen.

All dwarfs: The Queen! [They all look aghast] She's wicked.

Happy: She's bad.

Sneezy: She's mighty mean.

Grumpy: She's an old witch! I'm warnin' ya ! If the Queen finds her here, she'll swoop down... and wreak her vengeance on us!

Snow white: But she doesn't know where I am.

Grumpy: She don't, huh? She knows everything. She's full of black magic. She can even make herself invisible. Pfft! Might be in this room right now.

In this scene, the Dwarves construct the Queen as a powerful and ruthless woman who is "full of black magic" and will not hesitate to "wreak her vengeance" on them. Their claim that she is "knows everything" and has powers of invisibility constructs her as an omnipotent force to be reckoned with. Through the Dwarves' construction of the Queen, power and witchcraft are intrinsically linked. This supports the characterisation of the witch as a powerful woman who can destroy any individual that stands in the way of her ambitions (Aguiar, 2001; Ussher, 1997). It is also worthy 
of noting that they label her an “old witch.” Despite the Queen's attempts to preserve her beauty, she is still recognised as old. Being old can function to render a character powerless, although it can also function to depict her as "destructive and dangerous to society's stability and well-being" (Aguiar, 2001, p. 171). In this scene, the description of the Queen as a potent "old witch" aligns with the characterisation of the powerful witch. Later in the film, the Queen storms down to her lair to brew the potion the potion that will enable her to be disguised as a 'hag' and kill Snow. The lair is filled with items that connote her evil nature, such as her books on the black arts, alchemy, and potions. Distillation equipment is brewing magical potions. As she enters the chamber, she is greeted by a crow perched on a skull. She then concocts a potion that disguises her as an "old hag" with a croaky voice, wrinkles and a large, hooked nose topped with a wart. Through this scene, it is clear that the Queen is indeed a witch. Her transformation into an "old hag" conveys the connotation that the Queen's evil behaviour is reminiscent of an old conniving woman.

\section{The Queen and Her Ambition}

The Queen's ambition is another aspect of her representation as a 'bad woman.' While all of the Queens are ambitious, these ambitions have both continuities and divergences across the three films. In these three early films, the Queen seeks to advance her societal standing by marrying the King. However, the extent of her ambition differs. In the 1959 version, she seeks to expand her kingdom and conquer more land by attempting to kill Prince Charming. However, in the 1916 and 1937 versions, the Queen's ambition is not developed as extensively. In the 1916 version, the Queen is initially merely an "evil lady of the court" who plots to marry the King. With the aid of a witch, she is able to achieve a more attractive appearance and marry the King, thus becoming the Queen. In the 1937 version, the Queen is merely preoccupied 
with being the "fairest" and maintaining her position as Queen. There is no mention of how she rose to the position.

In contrast, the Queen is fiercely ambitious in the 1959 version of the film. In the following scene, for example, the Queen is standing with Count Oga on a balcony, as the palace official pronounces the King dead.

Palace official: The King is dead. Long live the Queen.

Queen: My hour has come at last [addressed to Count Oga].

Count Oga: There was never any doubt of it once I had signed the wizards to champion your cause.

Queen: I'm not exactly helpless without you [to Count Oga].

Count Oga: Far from it my lady. It was entirely your idea to have young Prince Charming discreetly done away with. I merely saw to it that your orders were executed.

Queen: You needn't make it sound as if I enjoy annihilating children, I only do it when it's unavoidable.

Count Oga: Of course your majesty. Your fierce ambition conceals the tenderest of hearts.

Queen: Yes, I must confess my conscience is always clear.

Count Oga: Exactly. If that idiot father had not betrothed Prince Charming to Snow White in childhood, why the lad would be alive today.

Queen: Don't be a fool. He had to die! Once he married Snow White he would have been king of two kingdoms and I would have been Queen of...none.

Count Oga: How bitter for you that Snow White will still ascend the throne when she comes of age, married or not.

Queen: If that is allowed to happen, let me remind you that my defeat is your defeat!

Count Oga: All I ever counsel is patience and caution dear lady. You are sometimes too impetuous.

Queen: I am a Queen! And I intend to remain the Queen. The world will look on Snow White's face no more.

In the above scene, the Queen is constructed as power- hungry and conniving. She discusses how she had Prince Charming murdered in order to secure the future of her kingdom. Count Oga describes her as having "fierce ambition." Being ambitious is a characteristic that does not adhere to traditional conceptions of ideal femininity (Aguiar, 2001). Ambition is often constructed as a negative disposition for women to have, for 
both fictional and real women (Aguiar, 2001). For example, Anne Boleyn was infamous for her ambition to be Queen, which was represented as being achieved through careful plotting and use of her sexuality, acts she was ultimately punished for (Warnicke, 1989). The character of Lady Macbeth is also an infamous villain whose ambition drives her to commit murder (Shakespeare \& Braunmuller, 2008). In Snow White, the Queen's ambition and greed is illustrated further in the following scene where she is conversing with Count Oga in her bedroom.

\footnotetext{
Queen: How I've hated wearing black. A whole year of it. One more day and my widow's weeds would have strangled me! Free at last!

Count Oga: And the all-powerful Queen of not one but both kingdoms - yours and Prince Charming's.

Queen: No woman ever possessed such power! You will arrange a national celebration to be held in my honour and it must be the most extravagant in history [throws her arms wide].

Count Oga: And we now touch upon a delicate subject your majesty. Your tastes could hardly be called frugal and the exchequer is in fact empty.
}

This scene supports the earlier characterisation of the Queen as overly ambitious. Her exclamation that "no woman ever possessed such power" suggests that her command over two kingdoms is uncharacteristic of a woman. In this sense her behaviour transgresses expectations of women. Her greed is also demonstrated in this scene. According to Aguiar (2001), the representation of ambitious women in media serves as a cautionary tale, providing the impression that that "thou shalt not let women have power" (p.36). There is a moral component to how the Queen is represented in the early renditions of Snow White. She demonstrates that if one does not adhere to the prized versions of femininity, one's behaviour will ultimately be punished. In Radway's (1981) examination of the Gothic romance, she also found that the 'female foils' were penalised for their desire to improve their social standing in society. In opposition to the heroine, the female foil is a character who is "motivated by extravagant ambition and simple greed" (Radway, 1981, p. 154). The Gothic's characterisation of the female 
villain has notable parallels to the Queen in the cinematic renditions of Snow White. They both have a desire for status and power, yet it is this very ambition that ultimately destroys them. However, it is worthy of noting that the Queen gained her powerful position by displaying these "bad" characteristics. This indicates that a woman's ability to rise to power may in part be facilitated by positioning themselves in opposition to traditional discourses of femininity. However, these powers are merely temporary, fading once they are faced with the goodness of the heroine.

\section{Chapter Conclusion}

In the preceding chapter, the analysis has focused on the manner in which the constructions of the female characters are positioned within discourses of femininity. In line with the dominant discourses of traditional femininity in circulation in the time period in which the three films were produced, Snow is constructed as caring, nurturing and maternal in each of the films. Snow's 'good girl' characterisation is furthered by her selfless suffering. In the 1916 and 1937 version, the Queen reduces Snow to servitude, an occupation that resonates with the broader social context where domestic servitude was a common occupation for women (Duffy, 2007). Despite being subjected to the Queen's numerous attempts to murder her, Snow's goodness and sweetness allows her to persevere. From her performance of domestic labour to her caring for the Dwarves, Snow personifies the conception of the 'good girl' who is eventually rewarded with her Prince Charming. However, the Queen is negatively represented as the 'bad women,' whose jealousy of Snow ultimately results in her death or loss of power. These representations operate within a moral discourse that privileges traditionally feminine behaviour while punishing behaviour that transgresses it. In opposition to Snow, the Queen is constructed as selfish and anti-maternal, reinforcing the representation of her as a 'bad woman.' The Queen is also constructed as ambitious, 
although this is framed negatively as a cautionary tale for women to refrain from seeking excessive power. Her alignment with witchcraft further supports the villainous depiction of her. The Queen is also vain and self-obsessed, which is juxtaposed with Snow's natural beauty, mobilising a moral discourse that pathologises the Queen's obsession with her appearance.

The binary between good and bad femininity has been identified as central to constructions of femininity (Radway, 1981; Ussher, 1997). This is also evident across the early renditions of Snow White, where Snow's virtue, maternalism and kindness are juxtaposed with the Queen's villainous behaviour. In a sense the Queen's 'badness' functions as a necessary foil to Snow's goodness, exaggerating the difference between these polar representations of femininity. Although female audiences may also identify with the Queen's behaviour, they are warned that her transgressions from traditionally feminine behaviour will ultimately be punished. In this sense, the Queen's ambition provides a potential space for rebellion, although such attempts are simultaneously undermined by the moral discourses operating. 


\section{CHAPTER FOUR}

\section{DISCOURSES OF FEMININTY AND MASCULINTY IN THE CONTEMPORARY FILMS}

\section{Chapter Introduction}

The following chapter will examine the discourses of femininity and masculinity that operate within Snow White and the Huntsman (2012) and Mirror, Mirror (2012). Postfeminism is an important and relevant context for this investigation of the more recent cinematic renditions of the tale. Gill (2007) suggests analysis of postfeminist media is best approached through the notion of a 'sensibility' which teases out the various constructions of postfeminist identities or subjectivities. Foremost features of postfeminist subjectivity include self-surveillance, self-discipline, and conforming to strict beauty ideals, all of which are constructed as empowering and self-chosen. Closely aligned with postfeminism is the concept of neoliberalism, which is the idea that individuals should be "self-managing, autonomous and enterprising" (Gill \& Scharff, 2011, p. 5). Gill also highlights how postfeminism constructs women's sexuality as their dominant source of power and as a means to social advancement. An important postfeminist discourse is girl power, defined by the notion that 'girls can do anything' and that they can succeed in fields that are traditionally masculine (Hains, 2007). The analysis will thus take into consideration how both of the films undergoing analysis are situated in the current neoliberalist, postfeminist social climate.

The chapter will examine how the circulation of girl power discourses in the current social context function to construct the character of Snow. While the fairy tale genre is traditionally defined by female characters being 'damsels in distress,' contemporary versions of femininity place emphasis on displays of independence and 'saving yourself.' The analysis will highlight how these 'new' representations of the 
ideal postfeminist subject encompass having leadership abilities and strength whilst simultaneously being considered heterosexually attractive. Beauty is crucial to attracting the Prince and of particular relevance to the analysis is the film's concern with the traditional 'happily ever after' narrative when juxtaposed with girl power. The following chapter will initially focus on masculinity, particularly the manner in which the male characters are positioned within hegemonic masculine discourses that privilege heroic masculinity. Although heroic masculinity is an important aspect of the characters' representations, more ambivalent versions of masculinity will also be examined.

\section{Masculinity}

Fighting is a central element of hegemonic masculinity (see introduction chapter) through the perceived risk - taking, physicality, and bravery that it involves (Connell \& Messerschmidt, 2005; Woodward, 2000). In Snow White and the Huntsman, the Huntsman and the Prince adhere to aspects of these traditional discourses of masculinity. They bravely fight alongside Snow in the battle against the Queen, allowing them to display their physical strength. Although the Huntsman and the Prince are both constructed in line with these hegemonic ideals, there are divergences in the manner in which they are represented. While the Huntsman is represented as a gruff, 'macho' man through his working-class background, the Prince is represented as more 'polished' through his upper-class background.

In addition to fighting, the Huntsman is also depicted as a 'drunkard,' an element of his representation that is salient in relation to hegemonic masculinity (Connell \& Messerschmidt, 2005). In the scene where the Huntsman is introduced to the viewers, he is visibly inebriated and is being kicked out of a pub by the owner. The following exchange then takes place between them: 
Pub owner: You owe me money for my pocket and money for the girl.

Huntsman: You're welcome to it when it comes out again [takes a swig from a jug of beer and throws a punch at the pub owner].

Pub owner: You've gone too far. I want my money.

The pub owner and the Huntsman then begin to fight. However, the Huntsman's intoxication prevents him from competently fighting and he is quickly overpowered by the pub owner. His humiliation is enhanced when he attempts to hit the pub owner, but misses and instead hits a horse which kicks him into a trough. The act of drinking is considered to be an integral aspect of adhering to the prescriptions of hegemonic masculinity (Campbell, 2000; Connell \& Messerschmidt, 2005). However, the pub owner's assertion that "you've gone too far" indicates that the Huntsman has lost control over his behaviour. According to Campbell's research on the drinking patterns of rural New Zealand males, one of the primary "disciplines of drinking" is the ability to exert control over one's liquor consumption (p.566). He claims that while consumption of large quantities of beer was central to being positioned within these discourses of rural, 'macho' masculinity, displaying an inability to maintain self-control distanced a man from this idealised version of masculinity produced within the context of the pub. In the above scene, the Huntsman reacts to being thrown out of the pub with physical violence, distancing him from the idealised stoic, controlled version of masculinity that was espoused in Campbell's study. This highlights the subtleties involved in performing the 'correct' version of masculinity. While fighting in the context of war is deemed a central element of hegemonic masculinity (Woodward, 2000), fighting in the context of drunkenly 'losing control' is perceived as deviating from prized versions of masculinity (Connell \& Messerschmidt, 2005).

Although elements of his behaviour distance him from hegemonic masculinity, the Huntsman's appearance is an element that aligns him with this traditional form of 
masculinity. He wears hunting clothes that resemble armour, and has long, unkept hair and facial hair. As grooming is consistent with more contemporary versions of masculinity (Benwell, 2003), his lack of care for his appearance signals a disavowal of these 'softer' new versions of masculinity. In contrast to the Huntsman, the Prince in Snow White and the Huntsman is more closely aligned with contemporary discourses of masculinity. According to Gill (2007), the dominant construction of the 'new man' includes an affinity for maintaining one's appearance. Compared to the Huntsman, the Prince's appearance is more groomed and his clothing is more polished, positioning him within the 'new man' discourses described by Gill.

According to Holt and Thompson (2004), the prevailing discourses of masculinity are inextricably tied to social context. They describe how transformations in the labour markets have made way for new versions of masculinity. This includes changes such as fewer possibilities for being a 'self-made man,' and having to compete with women for jobs. The authors describe how these insecurities regarding changes in the labour force parallel a fascination with "masculine icons such as the adventurer and the big game hunter," men who display "rugged individualism, an adventurous spirit, risk-taking, displays of physical prowess, and most of all, a high degree of personal autonomy" (p.426). The Huntsman is a character that embodies these idealised masculine characteristics. He works independently in a field that requires constant displays of physical strength and the ability to evaluate physical risks. Bordo (2000) claims that "today, with many men feeling that women - particularly feminists - have been pushing them around for a couple of decades, the idea of a return to manhood 'in the raw' has a fresh, contemporary appeal" (p.251). Although the majority of men recognise that they will never fulfil the ideal represented by characters such as the Huntsman, they nevertheless may seek to align themselves with this fantasy of the 'lone 
adventurer' who is not dependent upon anyone (Holt \& Thompson, 2004). This 'adventurer' ideal has notable parallels with the discourse of heroic masculinity.

As discussed in the introduction chapter, heroic masculinity is a pivotal aspect of hegemonic masculinity (Benwell, 2004; Connell \& Messerschmidt, 2005; Holt \& Thompson, 2004; Sparks, 1996; Wetherell \& Edley, 1999). In Snow White and the Huntsman, the characters are positioned within dominant discourses of masculinity that privilege heroic masculinity. In addition to being active and independent, the male characters display a desire to literally save Snow. For example, when the Prince is reunited with Snow, he expresses regret that he did not attempt to save her earlier, saying "If I'd known you were alive I would have come sooner." This statement constructs the rescue of Snow as the Prince's responsibility. According to Sparks (1996), leading men in films are required to display "heroic agency" in order to fulfil masculine ideals (p.348). Sparks claims that the recent fears of a 'crisis in masculinity,' and the popularity of the 'new man' have revived interest in the reaffirmation of heroic masculinity through films. Although the hero must endure hardship and distress, he is eventually rewarded with the love of a beautiful woman. Within fairy tales, this narrative of the Prince rescuing the helpless Princess is particularly pervasive. Kipnis (1994) highlights how this heroic ideal can have an influence on men's subjectivities, as they experience regret over not fulfilling these heroic prescriptions despite their awareness that they are aspirational.

The constructions of the male characters in Snow White and the Huntsman differ starkly from the more 'anti-heroic' construction of the Prince in Mirror, Mirror. In Mirror, Mirror, the traditional heroic discourses of masculinity have been replaced by more ambivalent discourses of masculinity that serve to complicate the concept of heroic masculinity. Benwell (2004) describes "antiheroic masculinity" as characterised 
by "ordinariness, weakness, and self-reflextiveness" (14). Benwell claims that the readers of men's magazine incorporate the heroic and the antiheroic in constructing their subjectivities. While the men desire to align themselves with heroic masculinity, if they fail to adhere to it they also draw on antiheroic versions. The use of irony is central to enabling the reader's disavowal of heroic masculinity, as they can ironically distance themselves by dismissing heroic masculinity as unrealistic and obsolete. In a similar sense, the Prince is simultaneously constructed as heroic and antiheroic. While elements of his character adhere to the conception of heroic masculinity, the difficulties with maintaining a heroic façade are also highlighted. For example, when the Prince encounters the Dwarves in the woods, he manages to fight against them for a substantial period before he is defeated and is tied up in a tree. When Snow first meets the Prince, she finds him hanging in the tree upside-down, shirtless and facing his male 'travelling companion.' Taken aback by the scene, Snow laughs at him, and the following interaction takes place:

Prince: Who laughs at us?

Travelling companion: We are in dire need of your help, ma'am. We were ambushed by seven dwarfs...

Prince: Bloodthirsty giants.

Snow: Giants?

Prince: We were outnumbered, we fought bravely, but they cheated.

Travelling companion: Young lady, if you would be so kind as to help myself and the honourable Prince...

Prince: Prince of Embarrassment.

In this scene, the Prince is positioned in both heroic and antiheroic masculinity. Although he displays competency at sword fighting, he is eventually defeated, constructing him as anti-heroic. When Snow sees him hanging shirtless, attempts are made to construct him as heroic thorough his humorous assertion that "we fought bravely, but they cheated." The use of the word "bravely" is particularly noteworthy, as 
bravery is a central element of heroic masculinity (Benwell, 2004). However, his struggle to maintain heroism is illustrated when he refers to himself as "Prince of Embarrassment."

Another element of heroic masculinity is the classic narrative of rescuing the damsel in distress. In Mirror, Mirror, this narrative is problematized. When the Queen seeks to court the Prince, she gives him a "puppy-love" potion to make him blindly devoted to her. Snow breaks this spell by kissing him. When the spell is broken, the Prince says "thank you for saving me." Later in the film, Snow prepares herself to fight against an evil forest creature. She locks the Prince and the Dwarves inside the house in an attempt to stop them saving her. As she stands outside she tells him:

Snow: You know, all that time locked up in the castle, I did a lot of reading. I read so many stories where the Prince saves the Princess in the end.

Prince: Open the door. Open the door, Snow.

Snow: I think it's time we change that ending.

Prince: No, you're messing with tried-and-true storytelling. It's been focus-grouped and it works. Just let me save you.

However, the Prince breaks out of the house and helps Snow defeat the evil beast. Although Snow is capable of 'saving herself,' the Prince still assists with fighting the Queen. Therefore, while the classic 'damsel in distress' narrative is problematized, it is not completely reversed. Rather, the hero and the heroine unite to fight the Queen. The film attempts to directly subvert the classic 'damsel in distress' narrative through drawing on postfeminist discourses of girl power (Gill, 2007). It is worthy of noting that the scene points out that the 'damsel in distress' narrative has "been focus-grouped and it works." This introduces humour into the scene, constructing the classic heroic narrative as obsolete. 


\section{Snow White as a Leader and a Fighter}

In line with Mirror, Mirror's reversal of the 'damsel in distress' narrative, both films also construct Snow as a leader and a fighter, capable of saving her kingdom. However, in both of the films, Snow initially doubts her leadership abilities. In Snow White and the Huntsman, one of the Dwarves hands her a sword while saying "we follow you Princess. In life and in death." She looks hesitant as she is handed the sword, indicating that she does not trust her capabilities as a leader. She later confesses to William “How do I inspire? How will I lead men?” In Mirror, Mirror, Snow experiences a similar pang of doubt concerning her abilities when she decides to leave the Dwarves' cottage. In the note that she leaves them, she writes: "I thought I was strong enough to do this, but I am not. I am not my father, much as I wish I was. I am not a leader." Snow's narrative of self-doubt occurs within a social context where women's leadership persists to not be regarded as normative (Lee, 2013). Lee (2013) explains how traditional discourses continue to underpin the manner in which female leadership is constructed, claiming that whereas men are expected to be "strong, tough, aggressive leaders," women are generally constructed as "warm, caring, compassionate caregivers" (p.301). The depiction of Snow as doubtful about her leadership abilities is consistent with the persistence of these conceptions of leadership as an inherent male capability. Although these traditional discourses of femininity continue to operate, Harris (2004) and Lee claim that the prevalence of female leadership is gradually increasing.

While both of the films depict the characters as struggling with their leadership abilities, they also highlight the ability for the girls to overcome these obstacles. According to Harris (2004), the promotion of leadership programs for young women is central to the construction of the ideal 'youth citizen.' She claims that young women are 
targeted as having the potential to spearhead social change. In line with the recent societal focus on women as leaders, Snow also eventually gains confidence in herself and becomes a fiercely dedicated leader. This ability to overcome obstacles and succeed mobilises postfeminist discourses of 'girls can do anything,' even succeeding in areas that are traditionally male (Gonick, 2006; Hains, 2007). An example occurs in a scene played out in Snow White and the Huntsman. Following the lifting of Snow's coma, originally induced by the Witch's poisonous apple, she emerges from the entrance of Duke Hammond's castle and approaches the crowd that is congregated outside. She then gives the following speech:

Duke Hammond: Death has favoured you.

Snow White: Death favours no man. We must ride like thundering waves under the tented battle flag of my father [spoken softly while looking up earnestly at Duke Hammond].

Duke Hammond: You must rest.

Snow: Frost to fire, to fire to frost [whispering].

Snow: Iron will melt but it will writhe inside of itself! [Spoken loudly to the crowd]

All these years all I've known is darkness

But I have never seen a brighter light than when my eyes just opened

And I know that light burns in all of you!

Those embers must turn to flame

Iron into swords

I will become your weapon

Forged from the fierce fire I know is in your hearts

For I have seen what she sees

I know what she knows

I can kill her

And I'd rather die today

Than live another day of this death!

And who will ride with me

Who will be my brother?

Crowd: Aye! [while lifting their fists in the air]. 
Her abilities as a leader are demonstrated as she performs the speech, her voice loud and filled with conviction as the male characters gaze up at her with admiration. As she concludes her speech, the villagers bow down to her, functioning to further highlight her power. The battle speech is a central feature of many war films, usually involving the leader making an impassioned speech to his army about the importance of pursuing their noble cause. This type of scene is consistent with traditionally masculine discourses of mastery and leadership (Lee, 2013). In Lee's (2013) research, the congresswomen she interviewed often reported that they felt compelled to position themselves within masculine discourses in order to be perceived as effective leaders. The women attempted to construct themselves as 'masculine' through using words such as "tough" and "fighter" in their online biographies. Similarly, in the battle speech, Snow uses words such as "fierce," assuring them that as their "weapon," she will be able to defeat the Queen. Her strength as a leader is heightened through her description of a metaphorical fire burning and igniting their desire to fight the Queen.

In addition to being represented as a leader, Snow is also depicted as a fighter. As mentioned earlier, fighting is a pivotal aspect of traditional discourses of masculinity, in part through the perceived display of physical strength and bravery (Day et al., 2003; Woodward, 2000). As fighting involves displays of physical aggression, it runs contrary to the traditional representation of women as not predisposed to display aggression. However, in both of the films, Snow is positioned as a fighter. In Snow White and the Huntsman, Snow leads an army of men to battle against the Queen. The army is traditionally an arena for hegemonic masculinity to prosper (Connell \& Messerschmidt, 2005; Woodward, 2000). This renders Snow's part in the army an act that transgresses traditional feminine discourses. At the end of the movie, Snow defeats the Queen in a swordfight, demonstrating her ability as a fighter. In Mirror, Mirror, Snow is similarly positioned within these traditional masculine discourses that privilege 
physical aggression. After the Dwarves teach her sword fighting, she engages in a sword fighting match with the Prince. In the following scene their disagreement centres on Snow's discovery that the Prince has been seduced by the Queen and the Prince's discovery that Snow is living with thieving Dwarves:

Prince: You're with the bandits?

Snow: You're with the Queen!

Prince: You're a traitor.

Snow: And you're a jerk.

[They fight]

Prince: All right, that's enough. Stop this at once. I can't fight you.

Snow: Why not?

Prince: Because you're a girl. I don't fight girls.

[She continues to fights him]

Prince: Perhaps I should reconsider.

As they continue fighting, it appears as though Snow is losing the battle. The Prince draws her close, dipping her down as if dancing with her. He tells her "If you weren't trying to stab me right now, I might be tempted to kiss you," to which she replies, "I guess I better keep trying, then." At the end, Snow wins the battle. While the Prince is writhing on the ground in pain, she asks him "why do you have to be so darn cute," before proceeding to punch him in the face. Willis' (2009) concept of hybridity is particularly useful for understanding the myriad of discourses that operate in relation to these constructions of the 'female fighter.' Hybridity is the notion that a multitude of discourses can be drawn upon when constructing one's subjectivity. In Willis' research, the girls she interviewed drew upon both masculine and feminine discourses of gender. For example, when a girl expressed her desire to pursue a traditionally masculine career path, she also outlined a potential occupation that was conventionally feminine. This hybridity is also evident in the above scene. On one hand, Snow's behaviour 
transgresses traditional discourses of femininity that deem fighting as 'unnatural' for women (Hains, 2007). Although the Prince is initially reluctant to fight her due to her gender, she outwits him and eventually wins. While her gender may serve as a barrier for her perceived ability to fight a man, she effectively overcomes it, positioning her within postfeminist discourses of girl power (Gill, 2007a). On the other hand, their fight is represented as playful and underscored by sexual tension between the characters. While Snow is represented as a fighter, she is also represented as a sexually attractive young woman. This enables her to be represented as feminine despite her performance of traditionally masculine behaviour. Snow thereby embodies hybrid femininity by appearing feminine and attractive in addition to being physically strong.

The hybrid forging of strength and beauty is further illustrated in Snow White and the Huntsman. Following her battle speech, Snow is shown leading her army into battle. Riding on the horse, she is clad in armour and has her hair tied back, further signifying her abilities as a warrior. However, as the army assembles in front of the Queen's castle, the Huntsman looks appreciatively at her while telling her "you look very fetching in mail [chainmail armour]." This statement contradicts the 'masculine' representation of Snow by constructing her as attractive to males. Willis (2009) highlights how the girls in her study described their "female hero" as a "strong female" who also adheres to idealised notions of beauty. Willis describes how "even whilst the female character is endowed with warrior-like markings that imply physical strength, the traditional notion of desirable female characters as aesthetically pleasing objects is not lost in this textually revised version of femininity" (p.106). Similarly, Harris (2004b) chronicles how young women are increasingly targeted by the army through a construction of the female soldier as a "successful and glamorous can-do girl who can now also excel as a fighting machine" (p.83). This is congruent with the representation of Snow as physically attractive in addition to being a fighter. 
The construction of Snow as attractive in addition to being tough is interesting in terms of subjectivities that can be fashioned from cinematic representations. Hains (2007) claims that the recognition of femininity and strength as not mutually exclusive can be both progressive and problematic. In her analysis of the animated television series My Life as a Teenage Robot, she found that the protagonist, Jenny, was unable to successfully negotiate between being regarded as conventionally feminine and heterosexually attractive in addition to being 'tough' and battling male villains. She remarked that this was not a normative representation, as the majority of girl power icons were able to embody strength and conventional attractiveness simultaneously. Hains points out that such a portrayal is often unrealistic, as the slender physiques of the girl power icons such as Buffy do not provide an accurate representation of the muscular strength required to defeat large, strong men in a fight. While the recent renditions of Snow White films espouse this hybrid version of femininity, achieving this idealised version of girl power femininity may be difficult to achieve. Willis (2009) states that while girls are instructed that they "can do anything," it "did not necessarily translate into a simplistic understanding of the challenges that girls describe facing in their everyday worlds" (p.111).

Across the films, Snow's clothing serves as a signifier of the competing discourses that operate in the construction of her character. In Mirror, Mirror, at the start of the scene where the Dwarves are teaching Snow to sword-fight, she is wearing a white ball gown while attempting to learn the tasks. She then tries on a range of outfits, all of them men's clothes apart from one frilly dress. She disapproves of all of these outfits before settling on her final outfit, consisting of long, loose black pants and a fitted waistcoat worn over a blouse. In doing so, Snow effectively rejects both the traditionally male and the traditional female subject position, settling on a hybrid between the conventionally masculine and feminine. In Snow White and the Huntsman, 
Snow is wearing a long, white dress while she is performing the speech prior to the battle. It is noteworthy that both films initially depict her in a formal white dress, which may signify her innocence, purity and femininity. However, in Mirror, Mirror, she sheds this white dress and chooses a fusion between the hyper-feminine and the traditionally masculine.

\section{Beauty, Postfeminism, Neoliberalism and the Queen}

Whereas Snow represents an idealised version of femininity though her beauty and tenacity, the Queen represents a version of femininity that is vilified in society. Furthering their oppositional constructions, Snow is effortlessly beautiful, while the Queen's appearance requires continuous work. The classic written version of Snow White is a tale centred on beauty. It is therefore not unexpected that the recent adaptations of the tale continue to place vast emphasis on beauty. However, it may be argued that the focus on beauty has been intensified in these recent versions. In particular, they highlight the vast effort required to maintain beauty, through natural or supernatural means. The Queen in Snow White and the Huntsman uses magic to align herself with normative standards of beauty, in contrast to the Queen in Mirror, Mirror who is shown engaging in an extensive beauty routine.

In Mirror, Mirror, the Queen carefully maintains her appearance through her elaborate beauty rituals, constructing beauty as achieved through 'hard work.' This construction invokes postfeminist discourses that privilege careful self-monitoring of one's appearance (Gill, 2008) . The scene where the Queen undergoes her "treatment" exemplifies this postfeminist rhetoric of femininity "as a bodily characteristic, requiring constant work" (Gill, 2007, p. 187). When the maid tells the Queen that the "treatment is ready," Brighton asks the Queen "treatment? Isn't that a trifle excessive?" to which the Queen responds "there's no such thing." The Queen, clad in a silk dressing gown 
with her hair up in a towel, is shown being led to into a room with three maids attending to her. As she lies on the bed, she has bird droppings applied as a face mask, slices of dragon fruit applied to her eyes, Rambutan fruits put on her toes, doctor fish nibbling at her manicured hands, and worms poured in her bellybutton. She then endures a bee sting on her lips, a scorpion stinging her stomach, and a snake massaging her arm. Afterwards, she has huhu grubs poured in her ears, and snails crawling on her skins. She finally has clay poured over her entire body. As she undergoes the treatment, she whispers to herself "tightening and brightening" repeatedly. As she is stung, she says "happy place, happy place" and "oh, that's always the worst part," illustrating that she is clearly not enjoying the beauty treatments that she willingly subjects herself to. This echoes Gill's (2007) claim that in the current postfeminist climate, subjecting oneself to oppressive beauty regimes is often constructed as voluntary. However, the scene also highlights the pain involved in the pursuit of beauty, running contrary to Gill's observation that practises such as cosmetic surgery are often depicted as pleasurable. It is noteworthy that these outlandish rituals are available in actual beauty spas. The only element of the treatment that is not realistic is the scorpion bite. The Queen's use of these treatments thus parallels a broader societal preoccupation with 'fighting' the onset of ageing using whatever means that are available.

The treatment scene described above resonates with dominant beauty discourses that are circulated in the current postfeminist climate. The neoliberalist concept of individual responsibility for managing one's own life is particularly salient in relation to the manner in which the Queen is positioned in this scene. In her discussion of discourses circulated in relation to aging celebrities, Fairclough (2012) describes how in this “increasingly individualistic culture, a woman's outward appearance represents her entire self-hood" (p.91). She discusses how maintaining a thin, youthful façade is thus central to being constructed as a 'good' neoliberal citizen who is able to exercise control 
over her life. In the scene of the Queen undergoing her 'treatment,' the camera lingers on her perfectly smooth, flat stomach and toned legs. Her ability to effectively 'fight' the ageing process positions her within these neoliberal discourses that are espoused in the current postfeminist climate.

Although the Queen's control over her appearance positions her within these neoliberalist discourses, the scene simultaneously constructs the Queen as 'desperate' to maintain her appearance. In the current postfeminist climate, 'letting yourself go' is denigrated, yet being excessively concerned with clinging to one's youth is also pitied (Fairclough, 2012). In the scene where the Queen undergoes her beauty routine, the maid administering the treatments smirks as clay pours over the Queen. As the Queen is lying covered in clay, she says "I can feel you smiling." This may function to invite the audience to smirk at the Queen too; a desperate woman subjecting herself to a torturous regime in order to fruitlessly compete with a younger woman for a man. In this sense the Queen is pitied for her excessive preoccupation with maintaining the ideal body.

Postfeminist discourses of self-surveillance are further developed through the Queen's conversations with the magic mirror. In Mirror, Mirror, the mirror is not male, but is in fact the Queen herself with minor changes. The mirror Queen is dressed more conservatively than the Queen and is wearing a high necked white dress, her hair demurely tied back. In the following scene, the mirror attempts to convince the Queen that she should marry the Baron by pointing out that the Queen is old and has few marriage prospects. When the Queen rejects the Baron as a suitor, the mirror responds:

Mirror: Trust me. I am, after all merely a reflection of you. Well, not an exact reflection. I have no wrinkles [whispers].

Queen: [Gasps and examines her face] they're not wrinkles, just crinkles.

Mirror: As you wish.

Queen: What do you suggest I do? 
Mirror: I suggest you marry someone rich. Quickly. Because one day soon, you will ask me who the fairest of them all is, and you won't like the answer.

As the original tale and its subsequent renditions feature a male mirror, this film's decision to feature the Queen as the mirror is particularly noteworthy. Feminist analysis of the original tale has focused on the 'male mirror' as a representation of the patriarchal gaze that objectifies women (D'Uva, 1992; Joosen, 2004), privileging youth and beauty (Parsons, 2004). However, in this version it is the Queen that is required to survey her own appearance. This positions the Queen within neoliberal discourses that place responsibility upon the individual to manage their own life (Gill \& Scharff, 2011). Evaluations of one's appearance thus reside from within the individual rather than from others. This self-surveillance bears a resemblance to Bentham's Panopticon prison, a circular prison where the prisoners were unaware of whether they were being watched by the guards and consequently began to self-monitor (Foucault, 1977). In a similar fashion, the evaluations of the Queen's appearance does not originate from a male voice, but from 'herself.'

Unlike the Queen in Mirror, Mirror who uses relatively natural means to maintain her appearance, the Queen in Snow White and the Huntsman resorts to 'consuming youth' from young girls in order to maintain her appearance. The Queen captures young girls and effectively drains them of their youth. When she has failed to 'consume youth' from enough girls, her appearance rapidly deteriorates to resemble that of an old woman. This also functions to represent beauty as needing vast effort to maintain. Furthermore, her beauty is directly linked to her powers in that as her appearance fades she is unable to perform her magic. In the following scene the Queen is standing in front of the mirror, touching her face to examine its signs of ageing. Her brother appears behind her, resting his head on her shoulders while she gazes into the mirror. The following conversation then takes place: 
Finn: Magic comes at a lofty price.

Queen: And the expense grows.

Finn: (the Queen's brother) You look...

Queen: Old..?

Finn: Tired.

Queen: My power... fades.

Finn: I have something for what ails you...

The Queen then looks over her shoulder to find a young girl trembling with fear. The Queen approaches her and drains her of her youth, leaving her an old woman. In return, the Queen's youth is restored, leaving her smiling and satisfied. It is worthy of noting that the Queen evaluates her own appearance in the mirror in this scene. She does not need to seek external validation for her appearance, but instead polices her own faults. While power and beauty are implicitly linked in Mirror, Mirror, this scene explicitly associates beauty with powers. As her appearance fades, so does her ability to perform magic. This particularly intense association between beauty and power echo postfeminist discourses that construct beauty as immensely empowering (Gill, 2007). Although the means to achieve beauty differs from Mirror, Mirror, both films represent beauty as requiring extensive effort. This representation of the Queens is aligned with dominant discourses of beauty that construct it as 'hard work,' and persistently able to be improved upon (Gill, 2007).

\section{The Queen and Sexuality}

The Queens are not merely defined by their pursuit of idealised beauty, but also by their pursuit of men. In both of the films, there is emphasis on the Queen's sexuality. In Mirror, Mirror, the Queen seeks to marry the Prince, going to great lengths to gain his attention, constructing her as a 'cougar' who seeks the attention of a younger man. The 'cougar' can be defined as a 'thirty-five+ woman who goes out hunting for younger 
men. A more predatory term than the objectified milf' (Gorton \& Garde-Hansen, 2013, p. 299). The term 'cougar' is interesting for a number of reasons. Research has focused on how the prevalence of the 'cougar' has recently been intensified across media platforms such as film and television (D'Enbeau, 2009; Kaklamanidou, 2012). The proliferation of the 'cougar' has been praised for its recognition of women as able to harbour sexual desires and the reversal the traditional tendency for men to date younger women (Kaklamanidou, 2012).

In a similar fashion, the Queen in Mirror, Mirror is also depicted as a 'cougar' that preys upon the Prince. When the Queen first meets the Prince he has just been robbed by the bandits and stands before her shirtless. As he tells her he has been robbed by bandits, she keeps staring at his chest, exclaiming "how absolutely terrifying [referring to the robbery]. And smooth and hairy [referring to his chest].” Uncomfortable with her interest, he awkwardly wraps his arms around his chest and asks for a shirt. She appears flustered with lust as she admires him, struggling to formulate sentences as she reluctantly requests a shirt for him. The Prince thus becomes subject to the "female erotic gaze" (Gill, 2007, p. 97). According to Gill (2007), men are not exempt from being sexually objectified in the current postfeminist climate. In particular, this is "an idealized and erotisised aesthetic showing a toned, young body" (p.97). The Prince adheres to this description through his youth and conventional attractiveness. This scene depicts the Queen as a predatory older woman sizing up her vulnerable prey. In a sense the Queen is endowed with power as she sits on her throne, objectifying the Prince through her gaze.

Although the scene highlights her ability to be a sexual predator, the Queen is ultimately unsuccessful at ensnaring the Prince, representing her as a 'pitiful cougar.' Mirror, Mirror thus constructs being a predatory 'cougar' as ineffective in attracting a 
man. Kaklamanidou (2012) claims that the 'cougars' depicted on television are often ridiculed for their attempts to ensnare younger men. She chronicles how the recent television series Cougar Town (2009 - present) initially focused on the main character of Jules dating younger men. However, the series rapidly shifted its focus to her dating more 'age- appropriate' men. The only character that remained a 'cougar' was Barb, who she describes as a "caricature of a desperate middle- aged woman, constantly on the prowl and trying to cling to her youth, resorting to even the most painful cosmetic surgery in order to do so" (p.83). In an interview with Julia Roberts (who plays the Queen) about the film, the interviewer refers to the Queen as a 'cougar,' to which she responds “don't ever call me a cougar” (Roberts, 2012). This suggests that the stigma attached to cougars may still persist.

Hollway's (1984) discourses of heterosexuality offer one way of reading the construction of the Queen as a 'cougar'. According to Hollway, there are three dominant discourses of sexuality. The first is the "have/hold" discourse, where the ultimate goal for women is monogamy and marriage. Women are intended to attract a man to marry them through their virtue and patient waiting. In opposition to this is the "male sex drive" discourse, where men are perceived as biologically inclined to reproduce with as many women as possible in a bid to maximise their amount of offspring. The last discourse is the "permissive" discourse, which aims to dispel the notion that sexuality has to occur within the confines of a relationship, recognising the desire for women to also enjoy the sexual freedoms of men. While the increase in the prevalence of the 'cougar' recognises the female desire for sex, traditional discourses of sexuality that condone men being the 'predators' simultaneously operate (Hollway, 1984). The Queen may have been punished for her display of sexuality as it runs counter to the dominant norms of sexuality that privilege men being the sexual aggressors (Hollway, 1984). Previous analysis of villainous women's sexuality has 
found that the women were often punished for their displays of sexuality (Radway, 1981; Ussher, 1997). In particular, Radway’s (1981) classic analysis of Gothic Romances found that the women who were sexually aggressive were rarely rewarded with love. Although the Queen's desire to marry the Prince is some sense positions her within the 'have/hold' discourse, she does not passively wait for the Prince to court her but instead actively pursues him. She does not merely seek the security offered by marriage, but also displays sexual interest in the Prince. This functions to constitute her subjectivity within the 'permissive' discourse described by Hollway.

In addition to being a 'cougar,' the Queen is also represented as a gold- digger. According to Glenn (2000), labelling a woman a gold-digger can function as a means to rob her of her power and respectability, in part through "the economic ambitions and their sexual assertiveness" that it involved (p.198). In the scene where the Queen meets initially meets the Prince she appears physically attracted to him. As he describes his kingdom, her interest intensifies:

Queen: Valencia, you say. I've never heard of it. Is it a wee hamlet?

Prince: No, quite the contrary. It's a bountiful province. We have many natural resources.

Gold, silver, bustling silk trade.

Queen: You don't say.

Queen: [to Brighton, her servant] Send out the invites. Alert the caterer. I want you to organize a ball like this kingdom has never seen before. We are gonna sweep this kid right off his feet.

Brighton: Uh... Forgive me, Your Majesty, but I don't understand.

Queen: Brighton, the Prince is rich. He's built like an ox. I'm going to marry him, and then my financial problems will be... solved.

In this scene, the Queen discovers the Prince's financial attributes. It is noteworthy that she is positioned within this 'gold- digging' discourse, as it is a central means to vilify women (Glenn, 2000). Brown (2005) describes how gold- digging is considered controversial as it counters "conventional American beliefs that all 
marriages should be based on true love.” (p.89). The Queen does not love the Prince, but merely requires his financial resources and youthful body. Drawing on Bourdieu, Brown claims that the classic 'gold- digging' scenario is based on the exchange of capital. While the man has economic capital, the woman offers her bodily capital. In this case, the Prince's youthful and muscular physique affords him bodily capital, while his resources enable him to have economic capital. The Queen, however, is merely in possession of bodily capital, although this is rapidly declining due to her age.

In Snow White and the Huntsman, the Queen is also represented as being sexually predatory and calculating in her ambition to gain resources. However, her acts are driven by a deep hatred towards men. In addition to seeking wealth, the Queen also seeks vengeance upon men. Unlike Mirror, Mirror, there is no attraction on behalf of the Queen. Rather, it is a calculated plot to gain control of the kingdom after the original Queen dies. As the narrator describes it, "taking advantage of his grief, a dark and mysterious army appeared and lured him into battle." After the king defeats the army, he encounters Ravenna (soon to be the Queen) chained up in the back of a cart and "so enchanted by her beauty was the King that he forgot, for the first time, his broken heart. And the very next day she would become his wife." However, the Queen murders the King on their wedding night. The narrator's description of her as "taking advantage" of him and the claim that she "lured him," constructs her as a manipulative, conniving woman who dazzles men with her beauty before deliberately destroying them. In her examination of Fatal Attraction, McRobbie (2009) highlights how the villain is defined by her sexual aggression. By utilising her sexuality, Alex is able to destroy a man's family, becoming as she terms it, a "contemporary witch" (p.35). In Snow White and the Huntsman, the Queen also utilises her sexuality to ensnare the King, although this is motivated by her hatred of men. In the following scene, the Queen is in bed with the King and prepares to kill him: 
King: You will be the ruin of me.

Queen: Indeed my lord.

Queen: I was ruined by a King like you. I replaced his Queen, an old woman. And in time I too would have been replaced. Men use women. They ruin us. And when they are finished with us they toss us to the dogs like scraps.

King: What have you given me [gurgling in pain]?

Queen: When a woman stays young and beautiful forever the world is hers [straddles him].

First I will take your life my lord [holds up dagger].

And then I'll take your throne [stabs him].

The representation of the Queen as a vengeful, 'man- hating' murderer aligns her with dominant discourses of 'bad femininity.' In the above scene, the Queen describes how "men use women. They ruin us. And when they are finished with us they toss us to the dogs like scraps." Through this statement, the Queen is constructed as a 'man-hating' woman who believes men only use women for their youth and beauty. As she kills the King, she is straddling him, a position that may function to highlight her sexual power and the threat that she poses to masculinity. This characterisation of the Queen is in accordance with McRobbie's (2009) analysis of the manner in which villainous women are constructed in media. She describes how in current postfeminist times, the feminist is often characterised as a militant woman who 'hates men' and seeks to destroy them through whatever means available. McRobbie uses the example of the play Oleanna, where a young woman and the feminist group she is involved with deliberately destroy the life of a university professor by accusing him of rape. This play was part of a broader societal 'backlash' against feminism, which was in part facilitated through these media constructions of feminists as 'man- hating' and dangerous. In a similar fashion, the Queen is constructed as viciously hating men.

\section{Postfeminist Romance}

While 'hating men' distances the Queen from conventional femininity, romance serves as means for femininity to be reassured. Like other media, romantic fiction also 
responds to the social climate that it is situated within, constantly evolving in line with the prevailing discourses that are circulated in society (Gill, 2007; Stacey \& Pearce, 1995). In the current social climate, postfeminist discourses coexist with the privileging of traditional aspirations such as marriage (Gill, 2007). Indeed, according to Gill, the reliance on texts with a romantic plot has become intensified in this postfeminist climate. She suggests that texts relying on narratives concerned with romantic love have become a vital form of security for their audiences due to the "increasingly competitive labour market and rising social secularization," such that romantic texts remain an important aspect of women's lives (p.225). Romance is an enduring narrative that persists to underpin interactions between men and women (Jackson, 1995; Stacey \& Pearce, 1995). Women are interpellated through the romantic narratives that are espoused through a variety of media outlets, such as film, television and magazines (Gill, 2007; Jackson, 1995). The fairy tale genre is defined by its emphasis on 'love at first sight' and 'happily ever after' (Stacey \& Pearce, 1995; Ussher, 1997) narratives that are also adopted by Mirror, Mirror despite otherwise drawing on postfeminist discourses.

Mirror, Mirror is the text that most closely adheres to the classical narratives of 'love conquering all' that is so popular in romantic fiction (Stacey \& Pearce, 1995; Tukachinsky, 2008). In Mirror, Mirror, elements of the traditional narrative of 'love at first sight' are drawn upon. When they first meet, the Prince and Snow display attraction towards one another, although they endure various obstacles before they declare their love for one another. This follows the traditional Gothic romantic narratives examined by Radway (1981), where the heroine and hero face a plethora of challenges before they are able to live 'happily ever after.' Although the Queen attempts to ensnare the Prince, by the end of the film Snow and the Prince are married in a lavish ceremony. Afterwards, Snow begins to sing "I believe in love" repeatedly, and all of the characters 
begin to dance to the tune. It is indicative of the postfeminist contradiction that the film promotes such a traditional romantic narrative when it otherwise made a conscious effort to promote postfeminist discourses of girl power. As discussed earlier in the chapter, Snow is represented as a fighter, a leader, and as a saviour of the Prince. Despite these divergences from the classic 'damsel in distress' narratives, traditional conceptions of married bliss continue to be pervasive. This is congruent with McRobbie's (2007) analysis of Bridget Jones, a character who is positioned within postfeminist discourses that privilege independence and sexual assertiveness. However, Bridget still dreams of her 'white wedding.' As Gill (2007) explains it, “women are endowed with choice so that they can use their 'feminist' freedom to choose to reembrace traditional femininity - white weddings, hen nights, the adoption of the male surname on marriage, etc. “ (p.243). While Snow is engaging in 'masculine' tasks such as fighting, her femininity is reassured through her marriage to the Prince.

While Snow's femininity in Mirror, Mirror is underscored by her positioning within romantic discourses, the Queen in Snow White and the Huntsman expresses a deep hatred of romance, positioning her outside of femininity as constructed within traditional romantic discourses. An illustration of this is when she tempts Snow White with a poisoned apple. Instead of disguising herself as an 'old hag,' she disguises herself as William when she offers her the apple. 'William' and Snow are alone in the Snowy forest when 'William' declares his feelings for her, telling her that he "would have done anything for you." After they kiss, he hands her an apple. As she eats it, it rapidly turns from bright red to black, rotting away. As she staggers back, choking on the poison, he menacingly tells her "you see child, love always betrays us" before transforming back into the Queen. In this scene, the Queen's display of cynicism towards romance becomes another signifier of her distance to conventional femininity. 
Although the Queen distances herself from romance, Snow also has minimal engagement with traditional romantic narratives in Snow White and the Huntsman. In this film, there is a notable divergence from the classic romantic narrative underpinning the fairy tale genre. There is no mention of marriage and monogamy. Rather than the focus on 'true love' between a Prince and Princess, Snow has two suitors, neither of whom she marries. Although not committing to either of the men, she does display the ability to attract the opposite sex. This enables her to be recognised as a sexually attractive female, positioning her within postfeminist discourses that privilege sexual empowerment (Gill, 2007).

\section{Chapter Conclusion}

The preceding chapter examined the prevailing discourses of masculinity and femininity in Snow White and the Huntsman and Mirror, Mirror. Situated in the current neoliberalist, postfeminist climate, the constructions of gender within these films are a radical departure from the classic fairy tale. In both of the films, Snow is not a helpless girl reliant on males to battle the Queen. Rather, she is a strong, independent female capable of fighting and leading men into battle. This construction of her as successful within fields that are traditionally male enables her to be positioned within girl power discourses. Although Snow is depicted as physically strong and capable, her femininity is simultaneously reassured through her conventionally feminine appearance and her sexual attractiveness to the male characters. In Mirror, Mirror, the traditional romantic narratives are also drawn upon, preserving Snow's construction as feminine despite the reversal of the 'damsel in distress' narrative. Concomitantly, heroic masculinity in Mirror, Mirror is problematized. In spite of the Prince's ability to fight and his desire to save Snow, he is unable to be positioned within these prized heroic discourses. On the contrary, the male characters are both positioned within these heroic discourses. 
However, in this version there is no focus on marriage and monogamy. In this sense, while there are divergences in the representations, both films draw on traditional and contemporary versions of masculinity and femininity. Although Snow represents an ideal version of femininity through her sexual attractiveness in addition to her 'sassiness' and 'toughness', the Queen is negatively constructed. In Mirror, Mirror this negative representation of the Queen centres on her construction as a 'cougar' and unsuccessful gold digger, while the Queen in Snow White and the Huntsman 'hates men.' Thus unlike Snow, neither of the Queens are able to be positioned within traditional discourses of romance. In this sense both the Queens challenge prescriptions of normative femininity. 


\section{CHAPTER FIVE}

\section{CONCLUSION}

\section{Chapter Introduction}

The goal of this thesis was to examine the continuities and divergences in the prevailing discourses of femininity and masculinity in cinematic renditions of Snow White from 1916 to 2012. A key point of interest was the subjectivities made available within these discourses. Accordingly, this thesis' analysis identified discourses and examined the way in which the main characters were positioned within them, particularly the characters of Snow and the Queen. By approaching the analysis from a genealogical perspective, shifts in these gendered discourses, and the subjectivities made available through them, were able to be examined. In particular, a key concern of this thesis was to examine the extent to which constructions of femininities may have transformed across different versions of the films in line with their broader sociopolitical context. Centrally, the thesis asked to what extent traditional discourses of femininity endured over time and how these may be contested in more recent versions through postfeminist discourses circulating in contemporary Western societies.

\section{Enduring Femininities}

Contemporary discourses do not simply replace traditional discourses, as these pre-existing discourses are enduring and continue to shape what meanings are made available (Davies, 2005). To illustrate the endurance of discourses, Davies (2005) employs the analogy of writing on parchment where the previous writing is still visible in spite of attempts to erase it. When reading the newer words, the older words thus become incorporated in the meaning made available. In the present research, older versions of femininity are not erased by the newer versions. One such representation of femininity that is enduring across the films analysed is the 'good'/ 'bad' femininity 
binary. As discussed throughout this thesis, a moral discourse around 'good'/ 'bad' femininity underpins the representations of femininity in all of the films. Indeed, the binary construction of 'good'/ 'bad' femininity have been identified as central to media representations of gender (Charlton, 2007; Griffin, 2004; Harris, 2004a; Ussher, 1997; Walkerdine, 1990) and classic fairy tale narratives (Jorgensen, 2013; Rowe, 1979). This binary also plays out in the characters of Snow and the Queen, mobilising a moral discourse that denigrates 'failed' versions of femininity.

Although the punishment of transgressive femininity is pervasive across the films, there is some divergence in the representation of 'bad' femininity. One such divergence is the extent to which the Queen is ambitious. In the first two films (1916 and 1937), her ambition merely extends to becoming Queen. However, in the 1959 version and in Snow White and the Huntsman, the Queen is fiercely ambitious. Neither of these Queens is content with merely one kingdom. In Snow White and the Huntsman, the Queen is described as having 'ravaged' entire kingdoms for their resources, and is unable to stop. In the 1959 version, the Queen also seeks to expand her influence by overtaking the Prince's kingdom. Although the Queens in both films are initially successful in their attempts to conquer more land, they are ultimately punished, mobilising a moral discourse. The failure of these ambitious women may be interpreted as a cautionary tale about allowing women excessive power. It is interesting that ambition is particularly vilified in these two films despite the differing social contexts. As traditional discourses of femininity prevailed in 1959, the vilification of ambition may be related to a broader cultural fear of women gaining excessive power. However, this negative representation of ambition is evident in Snow White and the Huntsman, a film produced in the current social climate where women's leadership and ambition are gradually becoming more prevalent (Harris, 2004b; Lee, 2013). 
In contrast to 'bad girl' versions of femininity, 'good girl' versions of femininity are primarily centred on goodness (Ussher, 1997), respectability, and caring (Skeggs, 1997). These constructions constitute the character of Snow White who is persistently represented as 'caring' and kind. Similarly, the representation of Snow as 'caring' and kind is persistent from the 1916 to the 2012 versions. Specifically, all of the films depict Snow as caring for the Dwarves (or the Stooges in the 1959 version), providing them with emotional support and showing concern for their wellbeing. This suggests that caring and kindness have remained important aspects of femininity despite transformations within social contexts. A moral discourse also operates in relation to these 'good' versions of femininity, rewarding Snow's goodness and caring with the love of a handsome Prince.

This moral discourse is also evident in relation to beauty across the films. Feminist analyses of media have identified beauty as central to representations of girls and women (McRobbie, 1991; Ussher, 1997). Fairy tales in particular have undergone scrutiny for their representation of beauty (Grauerholz \& Baker-Sperry, 2003; Joosen, 2004; Jorgensen, 2013; Parsons, 2004). Grauerholz and Baker-Sperry's (2003) content analysis of fairy tales found that beauty was a pervasive theme from the original versions to the late $20^{\text {th }}$ century. Analyses indicate that beauty is also a pervasive theme throughout the renditions of Snow White investigated in this study. As the classic tale is centred on "who is the fairest of them all," it is not surprising that the films repeatedly place emphasis on beauty. In all of the films, a moral discourse operates in relation to beauty, punishing the Queen for her vanity and rewarding Snow for her natural beauty. Radway (1981) also noted that the villains in classic Gothic Romances were pathologised for their vanity, while the heroines were unconcerned with their appearance and possessed a natural beauty. This is also evident across the renditions of the Snow White films. In contrast to the portrayal of the Queen's obsession with her 
appearance, Snow is consistently depicted as not concerned with her beauty. Rather, her beauty is effortless and natural. Despite discourses of beauty being central across the tales, it can be argued that the later versions place a particular emphasis on beauty, thus prompting an enquiry of their function in a postfeminist social context.

\section{Shifting Femininities: Emergence of a Postfeminist Fairy Tale?}

From the preceding chapter's analysis of discourses within the later films, it is evident that the constructions of femininity in these texts resonate with a postfeminist sensibility. As described in earlier chapters, elements of this sensibility include an emphasis on embodied femininity, rendering the possession of a youthful, 'sexy' body as central to femininity (Gill, 2007; McRobbie, 2009). Although there is a persistent focus on beauty across the texts, it could be argued that the later versions are more centrally concerned with beauty, echoing Grauerholz and Baker-Sperry's (2003) finding that the focus on beauty in fairy tales increased towards the end of the $20^{\text {th }}$ century. Although Grauerholz and Baker-Sperry did not situate their analysis within a postfeminist framework, their findings parallel previous observations that postfeminist media has placed increased emphasis on beauty (Gill, 2007; McRobbie, 2009). Throughout the renditions of the tale, beauty is implicitly associated with power through the frequent references to Snow's superior beauty and the romantic rewards she receives from it. However, in Snow White and the Huntsman, there is a direct association between beauty and power. Without young girls from whom to 'consume youth,' the Queen's magic powers simultaneously fade. This construction of beauty as intrinsically linked with power resonates with postfeminist discourses that consider the body as a site of empowerment, particularly a youthful, heterosexually desirable body (Gill, 2007).

The recent films also privilege postfeminist and neoliberalist discourses through their construction of beauty as 'hard work' and requiring vast effort to maintain. This is 
particularly evident in Mirror, Mirror in the scene where the Queen is depicted undergoing her lengthy beauty treatments. This representation of femininity as laborious thus invokes postfeminist discourses that construct femininity as a 'project' constantly requiring maintenance to be deemed acceptable (Gill, 2007). In a similar vein, Grauerholz and Baker-Sperry (2003) theorise that the increased emphasis on beauty in the later versions of fairy tales functions as a means of "social control" over women (p.711). They explain that as women were endowed with increased opportunities, it is necessary to control them through internal means such as their concern with their appearance. Their findings are also in accordance with neoliberal discourses within which women are increasingly compelled to self - monitor their appearance (Gill \& Scharff, 2011). These neoliberalist beauty discourses are particularly salient in Mirror, Mirror, most transparently in the scene where the Queen's mirror image critiques her appearance. Rather than an 'outside' male voice making these negative evaluations, it is the Queen herself who surveys her faults. In Snow White and the Huntsman, the mirror is male, although the Queen also surveys her own faults. In this sense, both of these contemporary films are products of a neoliberal society where self-management and continuous effort is central to femininity.

Consistent with these late films as situated in a postfeminist, neoliberal socio political climate, discourses of girl power are also drawn upon in their constructions of idealised femininity. Whereas the Queen represents ‘failed' femininity, Snow’s embodiment of girl power discourses enables her to be aligned with idealised post femininity. The transformation of Snow from suffering and helpless to independent and 'sassy' highlights the transformations that have also occurred to dominant discourses of femininity. The earlier films situated Snow within traditional discourses of femininity through the depiction of her continuous selflessness and endurance of hardship. She is effectively rendered the 'damsel in distress,' patiently waiting for her Prince to rescue 
her from her misery, supporting Ussher's (1997) observation that a narrative of salvation is central to the fairy tale genre.

However, in Mirror, Mirror, there is a conscious effort to reverse this narrative of salvation and provide an alternative to the characterisation of Snow as passive and helpless. In this film, Snow is consciously 'sassy,' independent and able to 'save herself,' positioning her within girl power discourses. This is particularly evident in the scene where Snow refuses the Prince's requests to help her fight the Queen. Furthermore, rather than the Prince breaking the Queen's spell by kissing Snow, it is Snow who kisses the Prince to lift the spell that has been cast on him. Similarly, in postfeminist media, there has been a proliferation in the representation of 'tough' women able to 'fight their own battles' (Harris, 2004a; Inness, 2004). As noted in the introduction, current girl power discourses are exemplified by the character of Katniss from The Hunger Games trilogy (Woloshyn et al., 2013). In these books and their subsequent cinematic adaptations, Katniss fights, hunts, and needs no man to take care of her. Additionally, she protects her love interest, Peeta, when danger arises. In a similar fashion to Mirror, Mirror, this reverses the classic fairy tale 'damsel in distress' narrative where the man rescues the woman. This portrayal of the 'empowered' female is in stark contrast to their earlier versions of the tale where the primary function of the male characters is to rescue Snow.

The centrality of girl power discourses to femininity in the films is further exemplified by Snow's leadership and fighting abilities. In these contemporary renditions of the tale, Snow is depicted as a leader, a quality that is traditionally perceived to be confined to males (Lee, 2013). In both of the late films, Snow is also a competent sword fighter, effortlessly battling against men, abilities that have been identified as central to hegemonic masculinity (Connell \& Messerschmidt, 2005; Day et al., 2003; Woodward, 2000). Despite her placement within these 'masculine' 
discourses, Snow's femininity is recuperated through simultaneously being situated within postfeminist discourses that privilege physical attractiveness (Gill, 2007). This is particularly salient in relation to the construction of Snow as a soldier. Although Snow is tough, she is simultaneously heterosexually desirable. This is in line with Willis' (2009) notion of hybridity which chronicles the manner in which both masculine and feminine discourses are employed in constructions of femininity. Similarly, Harris' (2004) analysis of the discourses operating in relation to adverts for females soldiers highlights the importance of 'sexiness' in addition to 'toughness' in the construction of the ideal postfeminist subject.

Although the late films espouse a version of femininity that draws heavily on girl power discourses, there is a perpetual oscillation between traditional and contemporary discourses of femininity. As chronicled by Isbister's (2009) examination of fairy tale narratives in contemporary chick lit, the idealised heroine is strong and intellectual whilst simultaneously domestically competent and able to secure her romantic interests. This complex entanglement of discourses "abjures women to conform to a particular glamorized traditional femininity whilst also appearing empowered and self directed in all aspects of life" (Isbister, 2009, p.4). In the late versions of the tale, this entanglement of discourse is also evident, although there are also divergences between the films.

Despite Mirror, Mirror's consistent construction of Snow within postfeminist discourses, it simultaneously positions her within traditional discourses that privilege women's role within the domestic sphere. Snow is depicted as confident within the domestic sphere, cooking elaborate meals for the Dwarves and exerting her 'feminine touch' on their home. As Hollows (2007) notes cooking is a pivotal element of the traditional characterisation of the 'housewife.' This enables Snow in Mirror, Mirror to 
be constructed within domestic discourses in a similar fashion to the earlier versions. However, domesticity is not as central to her characterisation as in the Disney version in particular. The domestic element is not included in Snow White and the Huntsman, which may represent a departure from traditional discourses of femininity.

The intertwining of traditional and contemporary discourses of femininity is further evident in the representation of romance. Although Snow is represented as a 'tough', empowered fighter in Mirror, Mirror, she is ultimately positioned within traditional romantic narratives through her lavish wedding and her marriage to the Prince. In line with the early versions, traditional romantic narratives are espoused, starting with 'love at first sight' and concluding with 'love conquering all' (Stacey \& Pearce, 1995). Where Mirror, Mirror differs from the earlier versions is in the progression of the romance. Whereas the earlier versions present a 'rose-tinted' perspective on romance this version depicts relationships as challenging and rife with conflict. In Snow White and the Huntsman, there are significant deviations from these traditional romantic narratives. In this version Snow has two suitors, although she marries neither of them. This represents a radical departure from the original tale and its early retellings.

In line with the contradictory representations of romance within these films, previous research is also conflicted in terms of the role of romance in the current social climate. Drawing on Giddens (1992), Stacey and Pearce (1995) claim that romantic relationships have enduring appeal. However, they contend that there is a lessened fascination with marriage within this social context as it no longer serves a direct utilitarian purpose in terms of financial security. However, Gill (2007) and McRobbie (2009) attest that the interest in romance has intensified in current times. Although marriage is not glorified in Snow White and the Huntsman, it continues to be an 
important part of the narrative in Mirror, Mirror. This is perhaps indicative of more plural stories and possibilities in circulation around romance and marriage. This is in step with more diverse living arrangements in social practises, such as deliberately refraining from marriage and the increased legalisation of same-sex marriage.

The contradictory representations of postfeminist representations of romance across the later films has notable parallels to the representation of romance in chick lit (Gamble, 2009; Isbister, 2009; Whelehan, 2009). In a similar fashion to Mirror, Mirror, Isbister chronicles how chick lit often deploys classic fairy tale narratives in their depiction of 'happily ever after' relationships. Despite the heroines' demanding careers, they still seek fulfilment through romance (Gamble, 2009; Isbister, 2009; Whelehan, 2009). This combination of independence, success, and traditional romanticism resonates with the postfeminist goal of 'having it all' (Gill, 2007; Moseley \& Read, 2002). Isbister describes this as the ability to "re- embrace institutionalised heterosexual ideals of marriage and family without contradicting feminist principles" (p.3). Mirror, Mirror also represents ideal femininity as being achieved through independence and 'sassiness' in addition to marriage.

Although there is a pervasive focus on romance in Mirror, Mirror, as there is in chick lit, these traditional romantic narratives have been transformed in line with postfeminist ideals such as personal transformation (Isbister, 2009). According to Isbister, although finding love remains important for the heroines, neoliberalist ideals of realising one's potential is depicted as their primary concern. In Snow White and the Huntsman, achieving the 'happily ever after' with a man is no longer essential, rather Snow's transformation from being the Queen's victim to being a powerful fighter is continuously highlighted. This absence of traditional romance is furthered by Gamble's (2009) examination of chick lits deliberately subverting the classic fairy tale romance. 
In the books she examined, the heroines were content with being single and did not pine for the security of matrimony. In a similar fashion, Snow White and the Huntsman represents ideal femininity as not necessarily being achieved through marriage. Despite the divergences between these two texts, they both resonate with the current neoliberalist, postfeminist socio-political context where traditional discourses privileging domesticity and romance coexist with contemporary discourses of female empowerment and limitless opportunities.

\section{Reflections}

In the present social climate, there is a persistent fascination with fairy tale narratives (Grauerholz \& Baker-Sperry, 2003; Isbister, 2009). This can be seen across various media platforms, where from reality shows to women's magazines the 'fairy tale romance' and the 'fairy tale wedding' continues to be relevant, especially in relation to romance. Although the present research focused on the fairy tale Snow White, it would be interesting to examine how these fairy tale narratives are employed across multiple media, given that there is a substantial body of media that directly employs fairy tale narratives (e.g the television series Once Upon a Time $(2011$ - present)) and cinematic renditions of fairy tales such as Hansel \& Gretel: Witch Hunters (2013)). In particular, it would be informative to examine the discourses of femininity employed across these texts.

More specifically, in relation to the current study, the lack of popular cinematic renditions of the tale from the 1960s to 2012 can be seen as a limitation. As secondwave feminism emerged during this time period, it would have been interesting to examine films situated in that social context. However, the absence of renditions of Snow White may be indicative of a time period where many women were beginning to grow more critical of the traditional discourses operating within fairy tales. Indeed, 
much of the feminist research emerging at the time was particularly concerned with the oppressive nature of fairy tales due to their patriarchal constructions of gender (Rowe, 1979). In future research, it would be interesting to examine other fairy tales produced within this particular time period. As Mirror, Mirror and Snow White and the Huntsman contain a variety of postfeminist discourses congruent with their social context, it would be worthy of noting whether films produced during the second wave of feminism would situate female characters within feminist discourses.

Although examining the progression of one fairy tale was interesting in terms of analysing the progression of dominant discourses of gender, it would be valuable to examine other tales as well. Cinderella, for example, is also a fairy tale that has endured consistent popularity and has produced many literary and cinematic renditions.

However, there were no current renditions of Cinderella which rendered Snow White as the fairy tale that holds most contemporary relevance.

Alongside considerations of limitations related to text selection, it is important to underline that, when conducting research within a feminist poststructuralist framework, there are multiple perspectives when interpreting a text (Weedon, 1997). According to this methodological framework, meaning is not confined to one 'truth,' but is fluid and subject to the discourses the individual is exposed to (Weedon, 1997). As noted in the methodology chapter, my analysis of these texts is influenced by the discourses that have been made available to me via my engagement with media, my education and society at large. My studies of feminism and media have enabled me to critically examine the discourses in these texts, but I am conscious that this may have provided me with a cynical approach to fairy tales. However, it is important to also acknowledge that I am simultaneously aware of the pleasures that I have derived from these classic fairy tale narratives. 
Although the current study's use of textual analysis enables the examination of the potential subjectivities made available, the role that fairy tales play in the construction of female subjectivities in the current social climate could be further examined through empirical audience research. This would enable the investigation of the manner in which the subjectivities in these fairy tales are being taken up and resisted. Investigating the relationship between audiences and these texts would enable further examination of the function these tales may serve in contemporary society.

\section{Implications for Audiences}

Despite the prevalence of postfeminist discourses in the current social context, the traditional fairy tale narratives evidently continue to be of relevance to audiences. This persistent fascination with fairy tales is evidenced by the current increase in media employing fairy tale narratives. As discussed throughout this thesis, media texts serve as important cultural resources for constructing one's subjectivity. Fairy tales, in particular, are worthy of analysis due to their enduring appeal to a wide range of audiences. The classic fairy tales continue to be read to children by their parents or in schools and most adults remain familiar with their plots. Although these tales are widely recognised by males and females from a diverse age range, the cinematic versions analysed in this thesis are principally addressed to young girls. A notable exception is Snow White and the Huntsman which is aimed at a more mature audience, although it may still be aimed at a predominantly female audience. It is therefore important to consider the potential subjectivities made available to young girls by the films.

Feminist researchers have expressed concern that the gendered constructions within fairy tales provide audiences with restrictive notions of femininity and masculinity (Fisher \& Silber, 2000; Harries, 2000; Rowe, 1979). In particular, Rowe argued that the glorification of romance in these classic narratives functioned to render 
women as subservient to men. This body of work has largely adopted a 'media effects' perspective that assumes audiences are unilaterally influenced by the content they are exposed to (Gauntlett, 2002). In contrast, the current research's poststructuralist framework would highlight the audience's ability to take up diverse subject positions within the discourses made available to them by the text through resisting, incorporating or transforming them, rather than being directly affected by them (Stainton Rogers \& Stainton Rogers, 2001). In a similar vein, Isbister (2009) explains how feminist researchers gradually began to argue that audiences were not 'cultural dupes' but able to construct diverse subjectivities from fairy tale texts.

Audience studies further reveal that fairy tales provide audiences with resources for constructing their gendered identity, while also highlighting the alternative subjectivities that can be fashioned (Atkins, 2004; Rice, 2000; Westland, 1993; Wohlwend, 2009). For example, Atkins (2004) conducted a discursive analysis of gendered discourses within fairytales and interviewed adolescent girls about the role fairy tales played in the production of their identity. Atkins concluded that while the tales provide narratives for valued performances of femininity, girls in current society are able to negotiate more diverse identities. Such findings demonstrate that the notion of fairytales as merely circulating stereotypic representations that audiences subsequently adopt is an excessively simplistic notion.

Specifically, in the current research, there are a variety of potential subject positions that are being made available from the discourses circulated within the films. As chronicled by Isbister (2009), feminist research on audience implications for fairy tale readers has recognised that female audiences are not restricted to merely identifying with the heroines. In these Snow White films, it is possible that the female audiences could also identify with the ambitious, vain character of the Queen rather than the potentially unattainable goodness represented by character of Snow. Although the 
Queen is eventually punished, she embodies a form of transgressive femininity that may be appealing to audiences. Furthermore, research acknowledges the enjoyment that can be derived from engaging with fairy tales (Isbister, 2009) and classic romantic narratives (Jackson, 1995; Radway, 1991; Stacey \& Pearce, 1995). Therefore, the centrality of romantic discourses in the films analysed can be a source of pleasure rather an inherently oppressive element of the narrative.

In Mirror, Mirror and Snow White and the Huntsman, the reliance on girl power discourses may provide audiences with more diverse subjectivities than the earlier versions. In the last two decades, girls have increasingly been provided with the impression that they have limitless opportunities and are able to achieve within areas that are traditionally male (Gonick, 2006; Harris, 2004a, 2004b). Analysis of girls' responses to The Hunger Games trilogy revealed that girls considered the heroine's embodiment of girl power to be positive and inspirational (Taber et al., 2013). However, these girl power discourses have also been critiqued for being intrinsically linked with consumerism (Gonick, 2006; Hains, 2007; Willis, 2009). This link between consumerism and girl power is particularly evident in media reports of the release of The Hunger Games inspired pink bow and arrows aimed at girls (Martinson, 2013). By purchasing this product, girls are able to tap into the 'empowerment' available through engaging in this form of pseudo archery, framed in the article as the "ultimate in girlpower outdoor play" (Martinson, 2013). Furthermore, the recent increase in girls participating in actual archery (White, 2013) is indicative of a strong relationship between young female audiences and the popular media texts that they are exposed to. As The Hunger Games has inspired girls to take up archery, it is likely that the constructions of the 'female fighter' in Mirror, Mirror and Snow White and the Huntsman would also enable girls to construct their subjectivities in line with girl power discourses. 
In spite of the present thesis focusing solely on the fairy tale Snow White, these texts are a merely one of a plethora of cultural resources made available to girls. Fairy tales are therefore just one of a variety of texts that audiences can draw upon in the construction of their subjectivity. These other texts variously conform to and resist the versions of femininity in the cinematic versions of Snow White. However, the notable continuity between Snow White and other media directed at a female audience is the continuous focus on beauty. Feminist researchers such as Wolf (1991) have critiqued this fascination with beauty as being deeply restricting for girls and women. As discussed previously, this focus on beauty has arguably intensified in the current social climate (Gill, 2007) and is not confined to fairy tales (Grauerholz \& Baker-Sperry, 2003). The continuous emphasis on beauty in the Snow White films may provide the viewers with the impression that attractiveness is essential to being perceived as a successful female. In spite of the late films' employment of postfeminist discourses in their construction of the female characters, 'having it all' still includes being beautiful and heterosexually desirable.

From 1916 to 2012, the versions of fairy tale femininity articulated in the texts have undergone marked changes, although there are also notable continuities. Across all of the films, natural beauty, inherent goodness, and an affinity for caring and nurturing is central to being a 'perfect' fairy tale heroine. Furthermore, these idealised versions of femininity were initially centred on passively enduring hardships and waiting for the 'happily ever after.' Contrastingly, in the films produced in 2012, the heroines became self-assured leaders and fighters. This positioned the heroines within girl power discourses that present a version of femininity where girls have limitless opportunities. On one level these 'empowered' representations would seem to satisfy the earlier feminist critiques of fairy tale heroines as victimised and helpless (Rowe, 1979). However, does seeing a fictional character competently fighting actually provide a 
space for subjectivities to be shaped accordingly? Critiques of the girl power movement have been conflicted on this issue, variously highlighting its inspirational aspects and acknowledging how it can also be unattainable and unrealistic (Gonick, 2006; Hains, 2007; Willis, 2009). The complexity in the potential subjectivities made available in the recent films is further evident in the entanglement of these girl power discourses with traditional aspirations such as marriage. In this sense is the 'empowerment' available through these 'sassy' and 'fierce' heroines diminished? Does the modern fairy tale heroine's desire to 'have it all' in the form of strength, beauty, and goodness produce anguish or does it reassure the viewer that femininity and 'toughness' are not mutually exclusive? These are questions that might fruitfully be explored in research with girls. 


\section{REFERENCES}

Aguiar, S. A. (2001). The bitch is back: Wicked women in literature: Southern Illinois University Press.

Ashcraft, K. L., \& Flores, L. A. (2003). "Slaves with white collars": Persistent performances of masculinity in crisis. Text and Performance Quarterly, 23(1), $1-29$.

Atkins, K. G. (2005). Investigating female identity formation: From fairy tales to fabulous lives. 65 .

Bacchilega, C. (1993). An introduction to the "innocent persecuted heroine" fairy tale. Western Folklore, 52, 1-12.

Benwell, B. (2003). Masculinity and men's lifestyle magazines. Oxford: Blackwell.

Benwell, B. (2004). Ironic discourse evasive masculinity in men's lifestyle magazines. Men and Masculinities, 7(1), 3-21.

Black, P., \& Sharma, U. (2001). Men are real, women are 'made up': Beauty therapy and the construction of femininity. The Sociological Review, 49(1), 100-116.

Bordo, S. (2000). The male body: A new look at men in public and in private. New York; Maidenhead: Farrar Straus Giroux.

Braun, V., \& Clarke, V. (2006). Using thematic analysis in psychology. Qualitative research in psychology, 3(2), 77-101.

Bromley, S., \& Hewitt, P. (1992). Fatal Attraction: The sinister side of women's conflict about career and family. The Journal of Popular Culture, 26(3), 17-23.

Brown, J. A. (2005). Class and feminine excess: The strange case of Anna Nicole Smith. Feminist review, 74-94.

Burr, V. (1995). An introduction to social constructionism.

Campbell, H. (2000). The glass phallus: Pub (lic) masculinity and drinking in rural New Zealand*. Rural Sociology, 65(4), 562-581. 
Cancian, F. M., \& Gordon, S. L. (1988). Changing emotion norms in marriage: Love and anger in US women's magazines since 1900. Gender \& Society, 2(3), 308342.

Cancian, F. M., \& Ross, B. L. (1981). Mass media and the women's movement: 19001977. The Journal of Applied Behavioral Science, 17(1), 9-26.

Chamberlain, S. (2005). Fantasizing infanticide: Lady Macbeth and the murdering mother in early modern england. College Literature, 32(3), 72-91.

Charlton, E. (2007). "Bad" girls versus "good" girls: Contradiction in the constitution of contemporary girlhood. Discourse: studies in the cultural politics of education, 28(1), 121-131.

Clarke, L., \& Griffin, M. (2007). The body natural and the body unnatural: Beauty work and aging. Journal of Aging Studies, 21(3), 187-201.

Connell, R. W., \& Messerschmidt, J. W. (2005). Hegemonic masculinity rethinking the concept. Gender \& Society, 19(6), 829-859.

Cottrell, W. (Writer). (1937). Snow White and the Seven Dwarfs.

D'Enbeau, S. (2009). Feminine and feminist transformation in popular culture: An application of Mary Daly's radical philosophies to Bust magazine. Feminist Media Studies, 9(1), 17-36.

D'Uva, M. (1992). Barthelme's "Snow White", Calvino's "The Castle of Crossed Destinies" and contemporary discourse on the fairy tale: Feminist and Foucauldian approaches. Dissertation/Thesis.

Davidson, J. (2007). Perceptions of commercialised social introduction amongst women Ashgate.

Davies, B. (2005). The subject of post-structuralism: A reply to Alison Jones. A feminist critique of education, 15, 96-109.

Dawley, S. (Writer). (1916). Snow White. 
Day, K., Gough, B., \& McFadden, M. (2003). Women who drink and fight: A discourse analysis of working-class women's talk. Feminism \& Psychology, 13(2), 141158.

Dow, B. J. (1990). Hegemony, feminist criticism and "The Mary Tyler Moore Show.". Critical Studies in Mass Communication, 7(3), 261-274.

Dubrofsky, R. E. (2006). The Bachelor: Whiteness in the harem. Critical Studies in Media Communication, 23(01), 39-56.

Duffy, M. (2007). Doing the dirty work gender, race, and reproductive labor in historical perspective. Gender \& Society, 21(3), 313-336.

Fairclough, K. (2012). Nothing less than perfect: Female celebrity, ageing and hyperscrutiny in the gossip industry. Celebrity Studies, 3(1), 90-103.

Faludi, S. (1999). Stiffed: The betrayal of the American man. New York: W. Morrow and Co.

Firestone, A. (2012). Apples to oranges: The heroines in Twilight and The Hunger Games. Of Bread, Blood, and The Hunger Games: Critical Essays on the Suzanne Collins Trilogy, 209-218.

Fisher, J., \& Silber, E. S. (2000). Good and bad beyond belief: Teaching gender lessons through fairy tales and feminist theory. Women's Studies Quarterly, 28(3/4), 121-136.

Flamiano, D. (2000). Covering contraception. American Journalism, 17(3), 59-87.

Foucault, M. (1977). Discipline and punish: The birth of the prison. New York: Pantheon Books.

Foucault, M. (1978). The history of sexuality: Volume 1, an introduction. New York: Vintage.

Gamble, S. (2009). When Romantic Heroines Turn Bad: The Rise of the Anti-Chicklit 'Novel'. Working Papers on the Web, 13. 
Gauntlett, D. (2002). Media, gender, and identity: An introduction. New York; London: Routledge.

Gavey, N. (2011). Feminist poststructuralism and discourse analysis revisited. Psychology of women quarterly, 35(1), 183-188.

Giles, J. (2007). Class, gender and domestic consumption in Britain 1920-1950 Burlington, VT; Aldershot, England: Ashgate.

Gill, R. (2007). Gender and the media. Malden, MA; Cambridge, UK: Polity Press.

Gill, R. (2008). Culture and subjectivity in neoliberal and postfeminist times. Subjectivity, 25(1), 432-445.

Gill, R., \& Scharff, C. (2011). New femininities: Postfeminism, neoliberalism, and subjectivity. New York; Houndmills, Basingstoke, Hampshire: Palgrave Macmillan.

Gillespie, R. (2000). When no means no: Disbelief, disregard and deviance as discourses of voluntary childlessness. Paper presented at the Women's Studies International Forum.

Glenn, S. A. (2000). Female spectacle: The theatrical roots of modern feminism. Cambridge: Harvard University Press.

Gonick, M. (2006). Between "girl power" and "reviving ophelia": Constituting the neoliberal girl subject. NWSA journal, 18(2), 1-23.

Gorton, K., \& Garde-Hansen, J. (2013). From old media whore to new media troll: The online negotiation of Madonna's ageing body. Feminist Media Studies, 13(2), 288-302.

Grauerholz, L., \& Baker-Sperry, L. (2003). The pervasiveness and persistence of the feminine beauty ideal in children's fairy tales. Gender \& Society, 17(5), 711-726.

Griffin, C. (2004). Good girls, bad girls: Anglocentrism and diversity in the constitution of contemporary girlhood. . New York: Routledge. 
Hains, R. C. (2007). Inventing the teenage girl: The construction of female identity in Nickelodeon's my life as a teenage robot. Popular Communication, 5(3), 191213.

Harries, E. W. (2000). The mirror broken: Women's autobiography and fairy tales. Marvels \& Tales: Journal of Fairy-Tale Studies, 14(1), 122-135.

Harris, A. (2004a). All about the girl: Power, culture, and identity. New York: Routledge.

Harris, A. (2004b). Future girl: Young women in the twenty-first century. New York Routledge.

Hatfield, E. F. (2010). "What it means to be a man": Examining hegemonic masculinity in Two and a Half Men. Communication, Culture \& Critique, 3(4), 526-548.

Hollows, J. (2007). The feminist and the cook: Julia Child, Betty Friedan and domestic femininty In E. Casey \& L. Martens (Eds.), Gender and consumption: Domestic cultures and the commercialisation of everyday life

Ashgate.

Hollway, W. (1984). Women's power in heterosexual sex. Paper presented at the Women's studies international forum.

Hollway, W. (1989). Subjectivity and method in psychology: Gender, meaning, and science. London; Newbury Park: Sage Publications.

Holt, D. B., \& Thompson, C. J. (2004). Man of action heroes: The pursuit of heroic masculinity in everyday consumption. Journal of Consumer research, 31(2), 425-440.

Inness, S. A. (2004). Action chicks: New images of tough women in popular culture. New York: Palgrave Macmillan.

Isbister, G. C. (2009). Chick Lit: A Postfeminist Fairy Tale. Working Papers on the Web, 13. 
Jackson, S. (1995). Women and heterosexual love: Complicity, resistance and change. In L. Pearce \& J. Stacey (Eds.), Romance Revisited (pp. 49-62). London: Lawrence \& Wishart.

Joosen, V. (2004). Feminist criticism and the fairy tale: The emancipation of 'Snow White' in fairy-tale criticism and fairy-tale retellings. New Review of Children's Literature and Librarianship, 10(1), 5-14.

Jorgensen, J. S. (2013). Gender and the body in classical European fairy tales. 73.

Kaklamanidou, B. (2012). Pride and prejudice: Celebrity versus fictional cougars. Celebrity Studies, 3(1), 78-89.

Kipnis, A. (1994). Men, movies, \& monsters: Heroic masculinity as a crucible of male violence. Psychological Perspectives, 29(1), 38-51.

Lakner, H. B., \& Paff, J. L. (1997). Dress and the female gender role in magazine advertisements of 1950-1994: A content analysis. Family and Consumer Sciences Research Journal, 26(1), 29-58.

Lang, W. (Writer). (1959). Snow White and the Three Stooges.

Langford, W. (1999). Revolutions of the heart: Gender, power, and the delusions of love: Routledge.

Lee, J. (2013). 'You know how tough I am?' Discourse analysis of US Midwestern congresswomen's self-presentation. Discourse \& Communication, 7(3), 299-317.

Lemish, D., \& Muhlbauer, V. (2012). "Can't have it all": Representations of older women in popular culture. Women and Therapy, 35(3-4), 165-180.

Leonard, D. (1982). Sex and generation: A study of courtship and weddings (Vol. SSP 231): Tavistock.

Lindholm, C. (1998). Romantic love and sexual behavior: Perspectives from the social sciences: Praeger. 
Loke, J., \& Harp, D. (2010). Evolving themes of masculinity in Seventeen magazine: An analysis of 1945-1955 and 1995-2005.

Lotz, A. D. (2001). Postfeminist television criticism: Rehabilitating critical terms and identifying postfeminist attributes. Feminist Media Studies, 1(1), 105-121.

Martinson, J. (2013). Gritty in pink: Hunger Games inspires bow and arrow toy for girls, The Guardian

McCabe, J., Fairchild, E., Grauerholz, L., Pescosolido, B. A., \& Tope, D. (2011). Gender in twentieth-century children's books patterns of disparity in titles and central characters. Gender \& Society, 25(2), 197-226.

McRobbie, A. (1991). Feminism and youth culture: From 'Jackie' to 'Just seventeen': Macmillan.

McRobbie, A. (2004). Postfeminism and popular culture. Feminist Media Studies, 4(3), 255-264.

McRobbie, A. (2009). The aftermath of feminism: Gender, culture and social change. Los Angeles; London: SAGE.

Moseley, R., \& Read, J. (2002). " Having it Ally": Popular television (post-) feminism.

Ostermann, A. C., \& Keller-Cohen, D. (1998). Good girls go to heaven; bad girls...'learn to be good: Quizzes in American and Brazilian teenage girls' magazines. Discourse \& Society, 9(4), 531-558.

Parsons, L. T. (2004). Ella evolving: Cinderella stories and the construction of genderappropriate behavior. Children's Literature in Education, 35(2), 135-154.

Radtke, H. L., \& Jacques, H. A. K. (2012). Constrained by choice: Young women negotiate the discourses of marriage and motherhood. Feminism \& Psychology, 22(4), 443-461.

Radway. (1981). The utopian impulse in popular literature: Gothic romances and "feminist" protest. American Quarterly, 33(2), 140-162. 
Radway. (1991). Reading the romance: Women, patriarchy, and popular literature: Univ of North Carolina Press.

Reay, D. (2001). 'Spice girls','nice girls','girlies', and 'tomboys': Gender discourses, girls' cultures and femininities in the primary classroom. Gender and Education, 13(2), 153-166.

Rothschild, S. (2010). Modeling the feminine: The princess story in twentieth-century American fiction and film. 70, City University of New York.

Rowe, K. E. (1979). Feminism and Fairy Tales. Women's Studies: An Interdisciplinary Journal, 6(3), 237-257.

Sanders, R. (Writer). (2012). Snow White and the Huntsman.

Scanlon, J. (2009). Bad girls go everywhere: The life of Helen Gurley Brown: Oxford University Press.

Sender, K., \& Sullivan, M. (2008). Epidemics of will, failures of self-esteem: Responding to fat bodies in The Biggest Loser and What Not to Wear. Journal of Media \& Cultural Studies, 22(4), 573-584. doi: 10.1080/10304310802190046

Shakespeare, W., \& Braunmuller, A. R. (2008). Macbeth: Cambridge University Press.

Singh, T. (Writer). (2012). Mirror, Mirror

Skeggs, B. (1997). Formations of class and gender: Becoming respectable.

Smart, B. (1983). Foucault, Marxism, and critique. Boston; London: Routledge \& Kegan Paul.

Sparks, R. (1996). Masculinity and heroism in the hollywood 'blockbuster'. British Journal of Criminology, 36(3), 348-360.

Stacey, J., \& Pearce, L. (1995). Romance Revisited. London: Lawrence \& Wishart. Stainton Rogers, W., \& Stainton Rogers, R. (2001). The psychology of gender and sexuality: An introduction: McGraw-Hill International. 
Taber, N., Woloshyn, V., \& Lane, L. (2013). 'She's more like a guy'and 'he's more like a teddy bear': Girls' perception of violence and gender in The Hunger Games. Journal of Youth Studies, 16(8), 1022-1037.

Taylor, A. (2012). 'The urge towards love is an urge towards (un) death': Romance, masochistic desire and postfeminism in the Twilight novels. International Journal of Cultural Studies, 15(1), 31-46.

Tukachinsky, R. H. (2008). Feminist and postfeminist readings of romantic narratives: Heterosexual romantic experiences versus Sex and the City. Feminist Media Studies, 8(2), 181-196.

Ussher, J. M. (1997). Fantasies offemininity: Reframing the boundaries of sex: Penguin Books.

Walby, S. (1997). Gender transformations. New York: Routledge.

Walkerdine, V. (1990). Schoolgirl fictions: Verso.

Warnicke, R. M. (1989). The rise and fall of Anne Boleyn: Family politics at the court of Henry VIII: Cambridge University Press.

Weedon, C. (1997). Feminist practice and poststructuralist theory. Cambridge, Mass: Blackwell Pub.

Wetherell, M., \& Edley, N. (1999). Negotiating hegemonic masculinity: Imaginary positions and psycho-discursive practices. Feminism \& Psychology, 9(3), 335356.

Whelehan, I. (2009). Teening chick lit? Working Papers on the Web, 13(September), EJ.

White, G. (2013). 'Hunger Games' movie stokes appetite for archery among girls, The Ledger

Wilkinson, S., \& Kitzinger, C. (1995). Feminism and discourse: Psychological perspectives: Sage. 
Willig, C., \& Stainton Rogers, W. (2008). The SAGE handbook of qualitative research in psychology. Los Angeles: SAGE.

Willis, J. L. (2009). Girls reconstructing gender: Agency, hybridity and transformations of 'femininity'. Girlhood Studies, 2(2), 96-118.

Wolf, N. (1991). The beauty myth: How images of beauty are used against women: W. Morrow.

Woloshyn, V., Taber, N., \& Lane, L. (2013). Discourses of masculinity and femininity in The Hunger Games:"scarred," "bloody," and "stunning". International Journal of Social Science Studies, 1(1), p150-160.

Woodward, R. (2000). Warrior heroes and little green men: Soldiers, military training, and the construction of rural masculinities. Rural Sociology, 65(4), 640-657. 